Article

\title{
Fortresses as Specific Areas of Urban Greenery Defining the Uniqueness of the Urban Cultural Landscape: Warsaw Fortress-A Case Study
}

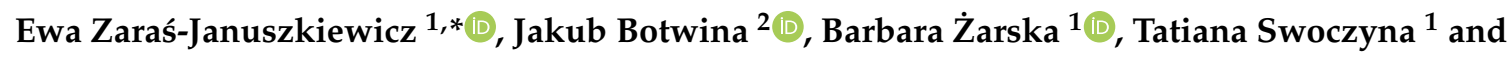 \\ Tomasz Krupa ${ }^{3}$ (i) \\ 1 Department of Environment Protection and Dendrology, Institute of Horticultural Sciences, \\ Warsaw University of Life Sciences, 02-787 Warsaw, Poland; barbara_zarska@sggw.pl (B.Ż.); \\ tatiana_swoczyna@sggw.pl (T.S.) \\ 2 Department of Landscape Architecture, Institute of Environmental Engineering, \\ Warsaw University of Life Sciences, 02-787 Warsaw, Poland; jakub_botwina@sggw.pl \\ 3 Department of Pomology and Horticulture Economics, Institute of Horticultural Sciences, \\ Warsaw University of Life Sciences, 02-787 Warsaw, Poland; tomasz_krupa@sggw.pl \\ * Correspondence: ewa_zaras_januszkiewicz@sggw.pl
}

Received: 13 December 2019; Accepted: 23 January 2020; Published: 1 February 2020

\begin{abstract}
The term "fortress landscape" is a holistic one which involves coverage and terrain adapted for defensive purposes. The specificity of the historical heritage of the Polish cultural landscape is expressed in a great number of such objects, some of which have been absorbed by its cities. A case in point is the Warsaw Fortress. A significant part of its fortification has survived to this day. Due to its spatial structure, manner of use and condition, the Fortress constitutes a valuable element of Warsaw's natural system. At the same time, it should be noted that this element is important due to being a tourist attraction and is an example of qualified military tourism. Military tourism is one of the most popular types of modern tourism. Its elements are frequently integrated into the urban green area system. Moreover, due to its specific spatial structure, the Fortress provides a unique element enriching the cultural landscape of the city. In this paper, a historical background of the Warsaw Fortress is analyzed with a special emphasis on its cultural value and public perception. The methods used in the study include a cultural value assessment, the WNET method, a survey questionnaire and both PCA and PCC statistical methods. The analysis showed that the landscape value of the Fortress received $70 \%$ of the maximum possible rating in the conducted survey. What is more, the Warsaw Fortress was also evaluated using all the assessment criteria. The study shows that the entry of the fortress elements into the city's natural system is perceived as being valuable, although it often lacks a specific program. Consequently, the Warsaw Fortress should be subject to landscape protection with a view towards revitalization, along with introducing a recreational program.
\end{abstract}

Keywords: fortress landscape; fortress; fort; city natural system; cultural landscape

\section{Introduction}

The term "fortress landscape" was introduced into the language of landscape architecture by Bogdanowski [1]. The term refers to a holistic form of coverage and landform adapted for defensive purposes. In addition to combat facilities, such landscapes also include non-combat constructions, such as engineering and logistics buildings, a barracks, road and railway objects, fire connections and greenery [2], which are currently viewed as communication links with accompanying avenue trees. Fortress landscapes are very important for a city's natural system due to their specific spatial structures and characteristic functional and spatial solutions in the field of greenery, whose remains 
are easy to detect in the fabric of the modern city. At the same time, these objects strongly fit into the landscape and can be part of the "showcase" of the urban silhouette. Examples include ring objects located in each of the partitions, such as the Prussian Torun Fortress, the Russian Osowiec Fortress and the Austrian Przemyśl Fortress, one of the largest facilities of this type in Europe (Figure 1).

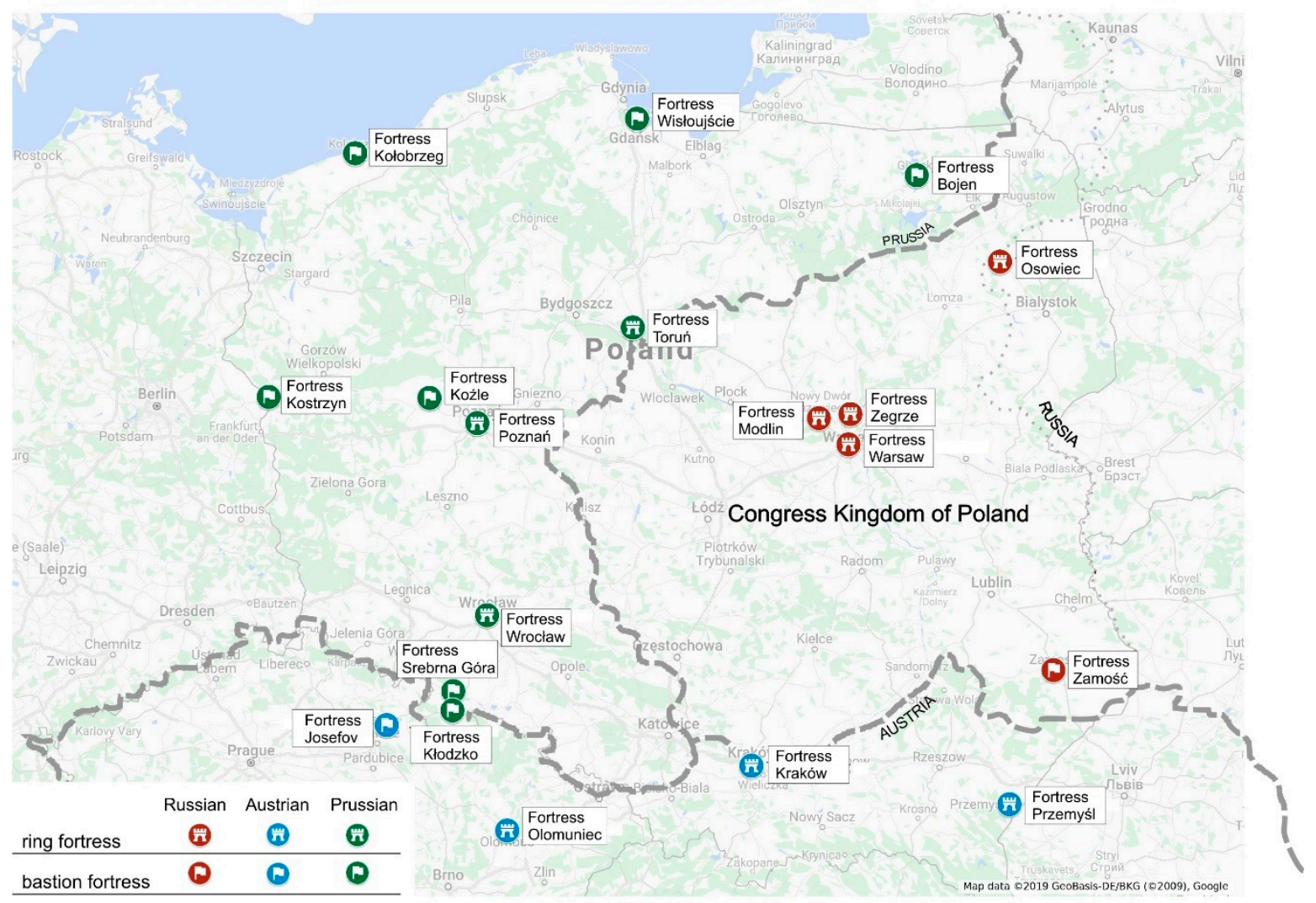

Figure 1. Map of selected forts in Poland against the background of the borders of three Russian, Prussian and Austrian empires after 1815 (Own study based on Google Maps,).

Not only are fortifications among the most architecturally and landscape-coherent objects, but, at the same time, they are significant surface areas of urban greenery, combined into a compact layout that often overlaps with the city's natural system. Due to the rapid density of the city and significant loss of greenery, understanding the potential of these places as multifunctional landscapes is crucial for the sustainable development of the city, comfort of life and health of residents. Little research on fortress landscapes and specific vegetation associated with them has addressed the problem of social and recreational values of this specific space, focusing mainly on observing existing users and their current activities on site.

The main aim of this work is to determine the specificity of the fortress as part of the green areas of the city, as well as its importance as a component of the city's sustainable landscape. Moreover, taking their position in public perception as exemplified by the Warsaw Fortress into account, their cultural value is established. A methodological approach, based on the use of various research and analytical tools (including assessment of the cultural landscape, scale of fortified landscape changes, attractiveness of fortress landscapes and the WNET method), is used to implement this assessment. The main thesis is: the fortress landscape is a valuable element of the cultural landscape, characterized by high specificity and uniqueness.

An extremely interesting example of the adaptation of defensive works to the contemporary needs of qualified military tourism is the reconstruction of the New Dutch Waterline, also known as the New Hollandic Waterline. This is one of the most interesting examples of the Dutch military heritage 
and its relationship to landscape design. The project not only revitalizes individual fortresses, but also strengthens the regional identity, which directly translates into increased tourist interest. It is an illustration of understanding cultural heritage as landscape and individual objects, as well as an example of reasonable interference in them. It also shows how dealing with these different scales can help in dealing with future spatial challenges. The transformation of the New Dutch Waterline from a large-scale military defense line to a tourism line has accelerated the civil use of historical military heritage as a tourism resource. The New Dutch Waterline has brought military heritage into fashion for new solutions, dedicated to the delivery of ecosystem services in cultural services. This reconstruction has helped society both to understand the historical dynamics of landscapes on a larger scale and recognize the value of our military past as part of regional identity $[3,4]$.

\section{The Unique Specificity of Fortress Objects in Ecosystem Services: Cultural Landscapes, Nature and Qualified Military Tourism}

Ecosystem services is a concept closely related to the environmental economy and the notion of natural capital. They are usually defined as the contribution of natural ecosystems to human well-being in the broadest sense. These services can be interpreted as income derived from natural capital. The aim of this concept is to "translate" the message of ecological sciences into a more accessible language of economics, thus contributing to preserving the environment in the most stable condition possible [5].

Gretchen Daily [6] has defined ecosystem services as states and processes through which natural ecosystems, together with the living organisms that are part of them, support and complete human life processes. They are responsible for maintaining biodiversity and producing ecosystem goods (production services). In addition, ecosystem services sustain life processes, such as waste absorption and processing, as well as regeneration processes (regulatory and living space services). Moreover, they provide many aesthetic and cultural benefits to humans (cultural services).

Nowadays, it is not possible to limit oneself to natural ecosystems alone, since they are difficult to find. That is why even the smallest biologically active surfaces, regardless of their origin, have become so valuable. For this reason, fortress buildings, of which greenery is an extremely important component, should be considered as valuable elements providing ecosystem services.

Fortress objects constitute an element conducive to the development of qualified tourism and recreation, performing a number of ecosystem services in each of the four categories. In the authors' opinion, the problems raised in the article are closely related in terms of the way the space is organized within the fortress landscape, including the share of biologically active area, various forms of greenery, including trees and bushes and water elements, architectural elements and the connection of individual objects with each other, as well as their connection with the natural system of the city, making these objects elements of a unique cultural landscape. A ring fortress is a special case, e.g., the Warsaw Fortress.

Therefore, the article focuses on a multi-faceted approach, defining the uniqueness of the fortress landscape in the context of the city. The objects described perform natural functions in a broader sense, entering the natural system of the city, combining individual and strategic parts of this system or being its nodal elements in themselves. They are also a kind of "reaches" connecting the natural system of the city with its surroundings. Moreover, they perform natural functions on a smaller, local scale. Due to the way such objects are used and exploited as green areas in the form of arranged parks or uncontrolled greenery, they constitute a valuable natural resource, being enclaves for many plant and animal species.

What is more, due to the presence of the historical buildings, fortress objects comprise a rich source of the cultural landscape closed in buildings, but are also found in a wider context in spatial arrangements, related to the terrain within the defensive work, as well as in the remains of deliberate planting, mainly comprised by trees. The plantings accompany defense works in various forms and have different purposes, making them an integral part of the whole defense system. Today, one can find only a few remnants of the plantings, the evidence of which is provided by the information 
found in archival iconography or descriptions. In the past, the historical tissue of the defense work was still present in a wider spatial range, related to the organization of even pre-shooting areas and communication links. The latter were covered by the urban tissue and became the canvas on which the street layout developed. Thus, it can be seen that these objects have a fundamental influence not only on the natural layer, but also on the layout and the composition of the city, both in terms of dominant views, such as the Citadel, and the very organization of urban space into parks or city-gardens.

The high value of the cultural landscape is strongly connected with landscape attractiveness. A highly valued landscape becomes attractive, which is the basis for a tourist/recreational product. Such a product, along with the programs offered by the location, are dedicated to various recipients, from the so-called qualified tourist, who is well-prepared and knows his or her expectations, to the visitors using such facilities in an undefined, casual, spontaneous and everyday way. That is why nowadays the cultural landscapes associated with defense are becoming so attractive, being not only an element of the urban space, but also part of leisure and educational programs.

Contemporary tourism/recreation is different to the way it was a decade ago. Today's consumer expects more from a tourism product. Therefore, for a product to attract a consumer, it must meet several criteria. The first one refers to its originality. The following ones have, in a sense, a secondary value, being connected with the preparation of the facility, making it available and programming it. In the Polish context, despite huge military resources being present in the country's landscape, few facilities were used to a high degree. This results from the fact that very often military objects were unavailable, as they were used exclusively by the Polish army. Fortunately, this has changed and nowadays they are obtaining new uses.

All of this forms an important component of the package of ecosystem services which are provided by the fortress elements of the cultural landscape.

Historical objects, preserved in a least changed form, are closely associated with tourist attractiveness. In the case of the Warsaw Fortress, historical resources have a very high value, due to the preservation of historical sights.

Fortified buildings of the Warsaw Fortress system, built or rebuilt at the turn of the 19th and 20th centuries, but also those built earlier, are characterized by a huge variety and interesting spatial solutions resulting from the specificity of military operations [1]. The basic distinction between types of fortress landscape involves the method of fortifying the object. To put it simply for the purposes of this study, such objects can be divided into bastion strongholds relating to their special form - star and ring strongholds. The first type includes single fortified objects, often with a starry outline of bastions. The second type concerns complex objects [2]. Their fortress elements consist of a citadel surrounded by rings of forts, usually bastions, and other fortress buildings. The layout of the ring fortress was associated with a much larger area where the defense work was carried out. Unfortunately, as history has shown, such solutions were not tactically effective. That is why few ring fortresses have survived to this day. However, there are similarities between all types of fortifications. An example of this is the behavior of extensive inter-fields due to the firing radius of weaponry. These spaces could not be built-up [2]. Also, various forms of vegetation with tactical functions, e.g., masking or obstacles, should be mentioned. Under the influence of the development of artillery and means of observation, the fortified landscape was constantly changing. Greenery played a major role in that process [2]. Today, these objects are valuable elements defining the uniqueness of the cultural landscape. At the same time, due to the outcomes of development and distribution, and the fact that such facilities were in many cases absorbed by cities, they perform a number of ecosystem services, being valuable elements of green infrastructure.

Today fortress landscapes have, above all, special systems of terrain in the form of erected elements, such as bastions, foreheads, cannon houses, moats, curtains and specific forms of greenery. From a natural point of view, the most significant are trees, possessing a historical and natural importance. Often, various animal species, e.g., bats, find shelter in historic and abandoned buildings (these areas are subject to environmental monitoring, and as many as 12 species have been found in the forts of the 
Modlin Fortress [7]). They are also home to interesting plant species (e.g., forts of the outer ring of the Warsaw Fortress).

One of the main elements of the sustainable development of cities, regions or other spatial units is proper management of existing resources. Under this perspective, the fortress landscape is an example of such a resource that should be used for the needs of organized tourism and recreation. Various processes meant that in the second half of the 20th century, tourism became one of the most important branches of the modern global and domestic economy, and its participation in the creation of domestic product of individual countries shows a clear upward trend [8]. In addition to many forms of mass tourism, modern types of individual tourism, including qualified tourism, are becoming increasingly important. Military tourism remains associated with visiting places and facilities of a defensive nature or is related to the history of armed conflicts, as well as the army and armaments, commanders and soldiers [9]. They have a diverse character, but their potential is undeniable, due to the natural attractiveness of the impressive oldest and newer fortifications, or even their ruins.

Tourist development of these places, understood as their adaptation to the needs of tourist traffic, is not only a matter of basic infrastructure or the form of access to sightseeing, but also a broader view on the issue of facility management and the resulting opportunities to create a competitive tourist site and thereby attract potential tourists.

Military tourism along the trail of the most famous fortifications is one of the most interesting sightseeing options available. It is estimated that in Poland there are about 16,000 various fortifications, ranging from defensive walls, through castles and fortresses, to defense complexes. For this reason, Poland is sometimes called the "military museum of Europe" [9]. Knowledge of the principles of shaping greenery within defensive works is particularly important in the process of revalorizing such objects, as well as in recreating the links between them. In particular, such principles are important in shaping connections between historical elements and the city's natural system. These connections should be considered from different angles, including compositional, natural and functional aspects. This is especially important when a defensive object is complex, creating a clear system of elements related to each other.

The greenery associated with a ring fortress, consisting of several separate defensive rings, was very important in shaping the defensive system. The outer rings were built from a series of forts, i.e., fortifications capable of independent defense. Its role was to move the enemy away from the center of the fortress $(6-10 \mathrm{~km})$. The inter-fields of the outer ring forts were protected by field fortifications, creating an airtight defense line. The inner ring, the so-called core (French: noyau), was usually a set of older generation works, e.g., bastion fortifications, protecting the fortress's rear in the event of the outer ring being broken by enemy units, e.g., cavalry. The core was separated from the center of the fortress by 3-5 km. The center of the fortress was often a city with a citadel, possibly the last center of resistance. Spatial forms of fortress greenery were correlated with the manner of conducting combat operations and reconnaissance methods. This arrangement is very clear in the case of the Warsaw Fortress, dating back to the nineteenth century. Model layouts of fortress greenery of the 19th and 20th centuries can be presented. Greenery in different forms fulfilled obstacle, masking, communication and garrison functions. One can distinguish six layouts of the fortress greenery. On the basis of Kraków's complex, individual systems are described and the appropriate functions are assigned to them [10-12].

The species composition of trees planted for military planting (used for fortifications) was predominantly comprised by native trees. Thanks to this, the defensive work was embedded in the landscape. Alien species had only decorative functions. The plot of the fort along with shelters and tunnels was covered with grass, made according to special instructions. The slopes were covered with a thick layer of soil, trees and sometimes shrubs. By using the arrangement of greenery and the occupied area (5-10 ha), the work resembled a park, integrating the object with the surroundings [13]. The functions and arrangement of forms of fortress greenery are presented in Table 1. Only direct warfare led to clearing the field of fire at a distance of a close rifle shot. All obstacles covering the view and limiting the firing field were removed. Grains, tall grasses, shrubs and young trees were cut. 
Branches of older trees were also trimmed within a radius of about $100 \mathrm{~m}$. In dense forest complexes, usually only the most important firing lines were cut [14]. Nowadays, it is advisable to preserve the historical form of objects.

Table 1. List of functions and arrangements of fortress greenery of the 19th and 20th centuries (based on references $[10,11])$.

\begin{tabular}{|c|c|c|c|c|c|c|}
\hline \multirow{2}{*}{ Function } & \multicolumn{6}{|c|}{ Arrangements of Fortress Greenery } \\
\hline & Superficial & Group & Background & Streaked & Rope & Point \\
\hline OBSTRUCTION & $\begin{array}{l}\text { spiky bushes, wide } \\
\text { stripes of trees, } \\
\text { knocking down } \\
\text { crowns towards the } \\
\text { enemy }\end{array}$ & $\begin{array}{l}\text { seemingly chaotic tree } \\
\text { groups that force the } \\
\text { opponent to remain in } \\
\text { the fire zone and } \\
\text { hinder the approach to } \\
\text { the fort }\end{array}$ & $\begin{array}{c}\text { more obstacle } \\
\text { lanes on the attack } \\
\text { line }\end{array}$ & $\begin{array}{l}\text { completing } \\
\text { technical } \\
\text { obstacles, } \\
\text { masking the } \\
\text { moat's edges }\end{array}$ & $\begin{array}{l}\text { a row of bushes } \\
\text { wrapped in } \\
\text { barbed wire }\end{array}$ & Absent \\
\hline MASKING & $\begin{array}{l}\text { deformation of the } \\
\text { outline and silhouette } \\
\text { of the object, visual } \\
\text { links between the fort } \\
\text { and the forest, the } \\
\text { grove }\end{array}$ & $\begin{array}{l}\text { the function is the } \\
\text { same as the surface } \\
\text { arrangement, but } \\
\text { these are smaller } \\
\text { groups of trees, which } \\
\text { better deform the } \\
\text { shape of the fort }\end{array}$ & $\begin{array}{l}\text { silhouette } \\
\text { masking, } \\
\text { combination of } \\
\text { planting with } \\
\text { existing greenery, } \\
\text { form used to mask } \\
\text { side-fire stations, }\end{array}$ & $\begin{array}{l}\text { used to mask the } \\
\text { edges of the moat, } \\
\text { silhouettes, } \\
\text { blurring } \\
\text { arrangement of } \\
\text { armored towers }\end{array}$ & $\begin{array}{l}\text { visual link } \\
\text { between the fort } \\
\text { and the greenery } \\
\text { of cemeteries, } \\
\text { farms and garden } \\
\text { greenery }\end{array}$ & $\begin{array}{l}\text { rarely planted } \\
\text { trees used to } \\
\text { deform the fort } \\
\text { outline, the } \\
\text { distribution of } \\
\text { shadows makes it } \\
\text { difficult to } \\
\text { observe the fort } \\
\text { from the air }\end{array}$ \\
\hline COMMUNICATION & $\begin{array}{l}\text { obstructing the course } \\
\text { of the road, its fork }\end{array}$ & $\begin{array}{l}\text { obstructing tactical } \\
\text { observation sites }\end{array}$ & $\begin{array}{l}\text { road protection by } \\
\text { plantings } \\
\text { detached from the } \\
\text { communication } \\
\text { system }\end{array}$ & $\begin{array}{l}\text { road protection by } \\
\text { plantings } \\
\text { detached from the } \\
\text { communication } \\
\text { system }\end{array}$ & $\begin{array}{l}\text { a row of trees } \\
\text { planted at an } \\
\text { angle to the road }\end{array}$ & $\begin{array}{l}\text { loose road } \\
\text { accompanying } \\
\text { system }\end{array}$ \\
\hline
\end{tabular}

The presented vegetation models can be used today to revitalize fortress buildings and adapt them within cities for recreational purposes.

\section{Materials and Methods}

The subject of the research is the Warsaw Fortress against the background of the Warsaw Fortified Region, which has three main fortresses and numerous fortifications complementing the system.

The research was carried out in three stages. In the first stage of field and office work, source materials were analyzed. The methodology of the study is based on the method of analysis and criticism of monographic literature known as the source criticism method, along with document research and a systematic review. Elements of the source material criticism were also used. A very important part of the source materials analyzed were historical iconographic materials including photographs, engravings, sketches and paintings. Historical materials regarding the establishment of the Warsaw Fortress and its location as part of the larger assumption of the fortress work, which was the Warsaw Fortified Region, as well as the compositional, communication, spatial and functional transformations that individual elements have undergone were analyzed in detail.

In the second stage, the components of the Warsaw Fortress defensive system were assessed, constituting an important element defining the distinctness of the city's cultural landscape (Table 2). When assessing the cultural landscape, the following criteria defined in the following table were adopted $[6,15,16]$ :

An important part of the assessment was to determine the scale of changes in combination with historical scratches and current development and use of the facilities.

The scale of changes affecting defensive structures is usually large. The modern model of the fort was created by combining three main and one additional determinants showing the direction of change (continuation, preservation, degradation and metamorphic determinants) as well as 3 determinants of the change causes (urbanization, agricultural and natural determinants). Different combinations of determinants allow for the presentation of nine main models for modern forts. 
Table 2. The Warsaw Fortress: criteria for assessing the cultural landscape, taking into account the specificity of the Polish cultural landscape, elaborated based on Myga-Piatek [15].

\begin{tabular}{|c|c|}
\hline Criterion & Punctation \\
\hline $\begin{array}{l}\text { antiquity (the older the landscape, the } \\
\text { more valuable the space) }\end{array}$ & $\begin{array}{l}\text { 3-landscape with historical elements older than } 300 \text { years } \\
\text { 2-landscape with historical elements aged } 100-300 \text { years } \\
\text { 1-landscape with historical elements younger than } 100 \text { years }\end{array}$ \\
\hline $\begin{array}{l}\text { historicity (the landscape is treated as a } \\
\text { form of cultural heritage, a source of } \\
\text { historical knowledge; this criterion is } \\
\text { proportional to antiquity) }\end{array}$ & $\begin{array}{l}\text { 3-landscape in which historical events of national importance have been recorded } \\
\text { 2-landscape in which historical events of regional importance have been recorded } \\
\text { 1-landscape in which historical events have not been recorded }\end{array}$ \\
\hline $\begin{array}{l}\text { authenticity (a landscape that has been } \\
\text { rebuilt many times cannot be authentic) }\end{array}$ & $\begin{array}{l}\text { 3-landscapes with fully authentic structural elements } \\
\text { 2-landscapes with structural elements slightly rebuilt or transformed } \\
\text { 1-landscapes with structural elements completely rebuilt, distorted }\end{array}$ \\
\hline $\begin{array}{l}\text { aesthetic value } \\
\text { (this is a very important value in the } \\
\text { assessment of the landscape, strongly } \\
\text { affecting our beliefs, it is not always } \\
\text { associated with authenticity, high } \\
\text { ratings for to this criterion can be } \\
\text { obtained for both historical landscapes } \\
\text { and reconstructed landscapes) }\end{array}$ & $\begin{array}{c}\text { 3-landscapes that give a sense of high aesthetics } \\
\text { 2-landscapes with slightly disturbed aesthetics } \\
\text { 1-landscapes with the presence of disharmonious elements } \\
\text { 0-disharmonious landscapes }\end{array}$ \\
\hline $\begin{array}{l}\text { harmony (the feeling that the landscape } \\
\text { structure is harmonious) }\end{array}$ & $\begin{array}{l}\text { 3-full compositional agreement giving a sense of order and spatial order } \\
\text { 2-slight compositional disorders } \\
\text { 1-compositional destruction, giving a sense of chaos } \\
\text { 1-visible compositional destruction, giving a sense of chaos }\end{array}$ \\
\hline $\begin{array}{l}\text { uniqueness (the landscape is original } \\
\text { and unique, meaning it has no } \\
\text { equivalent on a given scale) }\end{array}$ & $\begin{array}{l}\text { 0-total compositional destruction, } \\
\text { 3-original and unique landscapes on a national scale } \\
\text { 2-original and unique landscapes on a regional scale } \\
\text { 1-landscapes with typical and repetitive features }\end{array}$ \\
\hline $\begin{array}{l}\text { emotional value (the landscape can be a } \\
\text { source of emotions and feelings, which }\end{array}$ & $\begin{array}{l}\text { 3-local community shows a strong emotional relationship with the place in } \\
\text { surveys }\end{array}$ \\
\hline $\begin{array}{l}\text { determines the appearance of a sense of } \\
\text { attachment. }\end{array}$ & $\begin{array}{l}\text { 2-emotional relationships are only shown by specific groups (age, social) } \\
\text { 1-the local community does not identify with the place } \\
\text { 3-landscape used in accordance with the function, bringing economic benefits }\end{array}$ \\
\hline $\begin{array}{l}\text { value in use (landscape as a product for } \\
\text { which market laws apply) }\end{array}$ & $\begin{array}{l}\text { 2-landscapes used in accordance with the function, but not bringing economic } \\
\text { benefits; consequently, it has been exposed to change } \\
\text { 1-“for sale" landscape }\end{array}$ \\
\hline
\end{tabular}

For simplicity, the following determinants of change directions were adopted $[1,17,18]$ :

1. Continuity-maintaining features of the fortified landscape through limited continuation of its functions, e.g., the use of the fort area by the army.

2. Preservation-despite the loss of the fortified functions, the transformations do not disturb the specific conditional and signaling features of the system:

conditional features-these are the most durable forms of landscape (form of shape and coverage, characterized by a slow cycle of transformation and succession), which determined the location of the defensive structures.

signaling features-these are forms of coverage and landscaping that have arisen as a result of adapting the landscape to military operations:

shaping elements: embankments, moats, access roads, embankments, excavations, etc.

covering elements: fortification works, masking stands, observation points, etc.

3. Degradation - the changes have blurred the listed features

4. Metamorphism-new changes contribute to the creation of new values at the expense of fidelity to the historical model. New values are not always treated as negative elements, especially when the military object is included in an urban landscape.

When determining the emotional value, a non-standardized simple interview method was used based on a free interview with the modified Likert scale.

During the field work, material was collected in the form of a survey regarding the assessment of the attractiveness of fortress buildings. The study was conducted on a group of 200 people. The survey questionnaire included the following questions, as presented in Table 3. 
Table 3. Survey questionnaire (original study).

\begin{tabular}{|c|c|c|}
\hline No. & Questions & Answers \\
\hline \multirow{6}{*}{1} & \multirow{5}{*}{ How do you rate the attractiveness of the object? } & 5-attractive \\
\hline & & 4-positive \\
\hline & & 3-neutral \\
\hline & & 2-negative \\
\hline & & 1-definitely negative \\
\hline & \multirow{3}{*}{ Are the facilities available? } & 3-available areas \\
\hline \multirow[t]{2}{*}{2} & & 2-restricted access areas \\
\hline & & 1-areas not available \\
\hline \multirow[t]{2}{*}{3} & \multirow[t]{2}{*}{ What do you know about the history of the object? } & $\begin{array}{l}\text { 2-I have some knowledge of the object's history. } \\
\text { 1-I don't know anything. }\end{array}$ \\
\hline & & 2-often visited. \\
\hline \multirow[t]{2}{*}{4} & \multirow[t]{2}{*}{ What is the frequency of visiting the facilities? } & 1-sporadically visited. \\
\hline & & 0-never visited. \\
\hline \multirow{3}{*}{5} & Do you see the need to promote the object & $2-$ I often see such a need. \\
\hline & accompanied by a better, more intensive & 1-I see such a need sporadically. \\
\hline & development of facilities & $0-$ I never see such a need. \\
\hline
\end{tabular}

The respondents were divided according to their:

- $\quad$ gender: $\mathrm{F} / \mathrm{M}$

- $\quad$ age: (1) 30-34; 2) 35-3; 3) 40-44; 4) 45-49; 5) 50-54

- education: H—high; S-secondary; V—vocational

The obtained results were subjected to principal component analysis (PCA). Pearson's correlation coefficients (PCC) were also used, determining the level of linear relationship between random variables, which were used to present the relationship between the respondents' characteristics (age, gender and education) and the attractiveness of the fortification objects. The results are also given in percentages for individual groups of respondents.

In the field work, which included the preparation of photographic documentation of elements of the Warsaw Fortress system, the focus was on the analysis and its confrontation with the written and iconographic source materials. It was also crucial to analyze the existing tree structure within selected fragments of the defensive work of the Warsaw Fortress and to link them to the Urban Natural System.

The WNET method was used to supplement the assessment of the landscape value of the examined objects $[19,20]$. This method is based on the statement that the more natural (or almost natural) the elements are, the higher the landscape and ecological values become. It should be noted that the fortress buildings in their current condition and manner of use are characterized by a high proportion of natural elements related to the presence of vegetation and water. The most important factor giving the opportunity to correctly assess the landscape is the selection of diagnostic features that indicate the number of natural elements in the field. This selection is made on the basis of available source materials. Cymerman and Koc suggest the following diagnostic features:

- plant cover: 2-rich plant cover with mature stands; 1 -plant cover in poorer form, e.g., with poorly developed stands or without them; 0 - cover in damaged form,

- $\quad$ water: 2-current water-related elements; preserved in good condition; 1 -current water-related elements, used differently; no water, 0 -no water-related elements,

- degree of land use: 2-area with a specific program; 1-wasteland spontaneously used; 0 -degraded wasteland, unused land,

- landscape protection: 1 -there are forms of protection; 0 - no forms of protection.

In the third stage of work, a summary of the obtained data and formulation of conclusions was made. 


\section{Results}

\subsection{Historical and Spatial Characteristics of the Warsaw Fortress}

The Warsaw Fortress is located in the capital of Poland, in Central Europe. However, the territory of Poland in the years 1772-1918 was divided between three partitioners: Habsburg Austria, the Kingdom of Prussian and the Russian Empire. Warsaw was in the Russian partition. The first elements of the fortress were built in 1832 and the expansion of the fortifications continued until 1913.

Originally, the entire fortification complex consisted of defensive structures arranged in a specific manner, in accordance with the principles of defense art characteristic of the 19th century. Only 33 elements of the Warsaw Fortress have survived to this day. The Warsaw Fortress is an example of the unique fortresses of this time.

The Warsaw Fortress is also an example of unique fortress landscapes on a European scale. Due to the state of preservation and readability of the system, it is associated with the spatial order typical for ring fortresses. The location of individual elements of this system in the context of the contemporary area of Warsaw is extremely interesting. It largely coincides with the layout of the city's natural system. The Fortress constitutes a fragment of a larger military assumption-the Warsaw Fortified Region (WRU)_WRU (Russian: Варшавской укрепленной район, also known as the Warsaw Fortress District). It was a fortified area at the end of the 19th century, located at the time at the western edge of the Russian Empire. Its project assumed the use of existing fortresses in Modlin (the Modlin Fortress) and Warsaw (the Warsaw Fortress) and new planned facilities as the basis for operations against Germany and Austria-Hungary. The concept of the district was a development of ideas existing since the Napoleonic times to defend this area based on the fortress triangle. The concept was reintroduced during the expansion of the fortresses in Warsaw and Modlin. General-Governor Josif Hurko was a supporter of the expansion and supplementation of these fortifications. The Fortress Region was established in 1887 [21].

The Fortified Region was limited by fortifications, arranged in a simplified manner on a triangle plan, hence this area was also called the "Polish triangle" (Figure 2). Two of its corners formed the already mentioned fortresses, the third was to be the Zegrze Fortress. The top pf the system associated with the fortifications of Warsaw is particularly interesting because of its merging into the city.

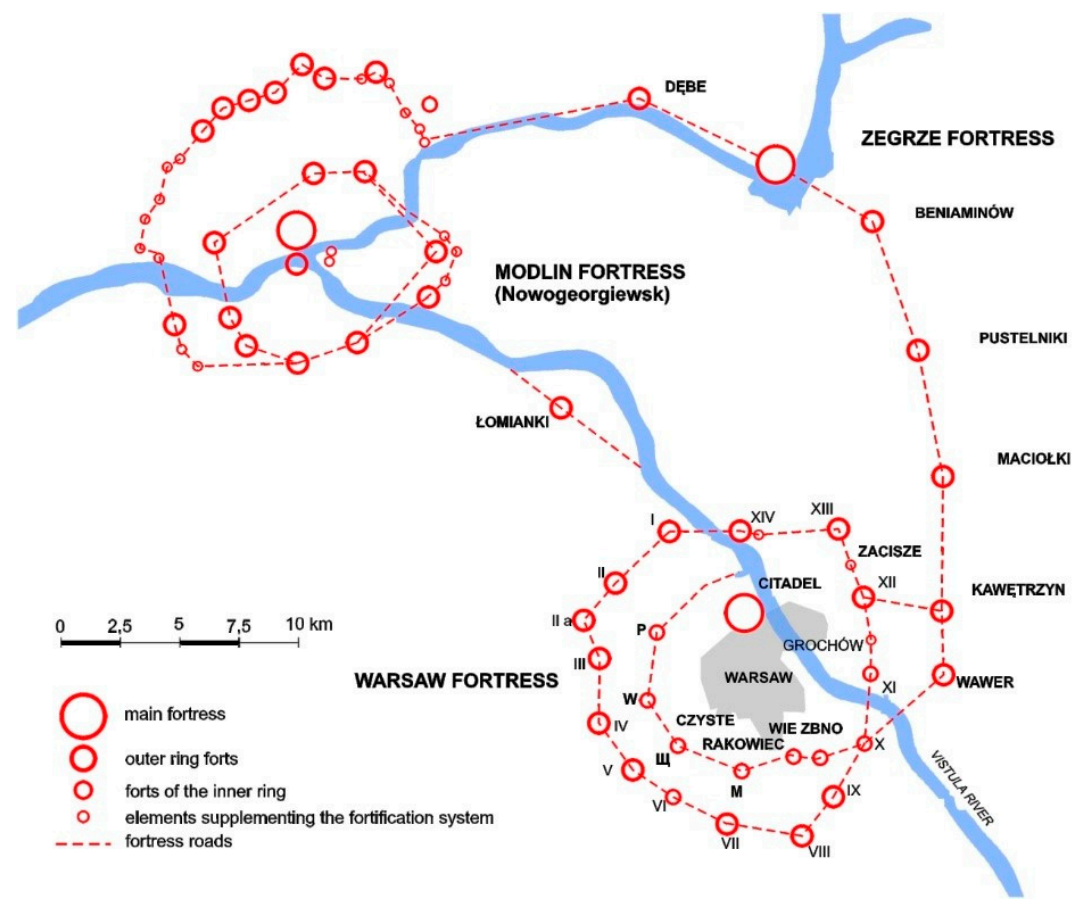

Figure 2. Diagram of the Warsaw Fortified Region (Own study). 
The Warsaw Fortress project was developed in the years 1818-1825 [22]. As the first element of the military system, the Warsaw Citadel, called Aleksandrowska, was built in 1832-1834, which was the heart of the Warsaw Fortress system. The citadel, surrounded by forts, is treated as the core of the fortress. The first external fortification work was the Śliwicki (Jasiński) Fort, erected in 1838, on the right side of the Vistula [21].

At the beginning of the 1880s (1883), the construction of the outer ring of the Warsaw Fortress began. The outer ring was designed at a distance of $8 \mathrm{~km}$ from the then city center. The main line of the ring consisted of 14 forts. Each of the forts of this ring was about 3-4 km apart. On the left bank of the Vistula, an additional four fortification works were designed on the fort inter-fields [23]. Three years later, in 1886, the construction of the inner ring began (Figure 3). The construction of the right-bank forts was completed in 1886, the left-bank outer line was completed two years later. In 1890, the construction of the left-bank forts of the inner line was completed [21].

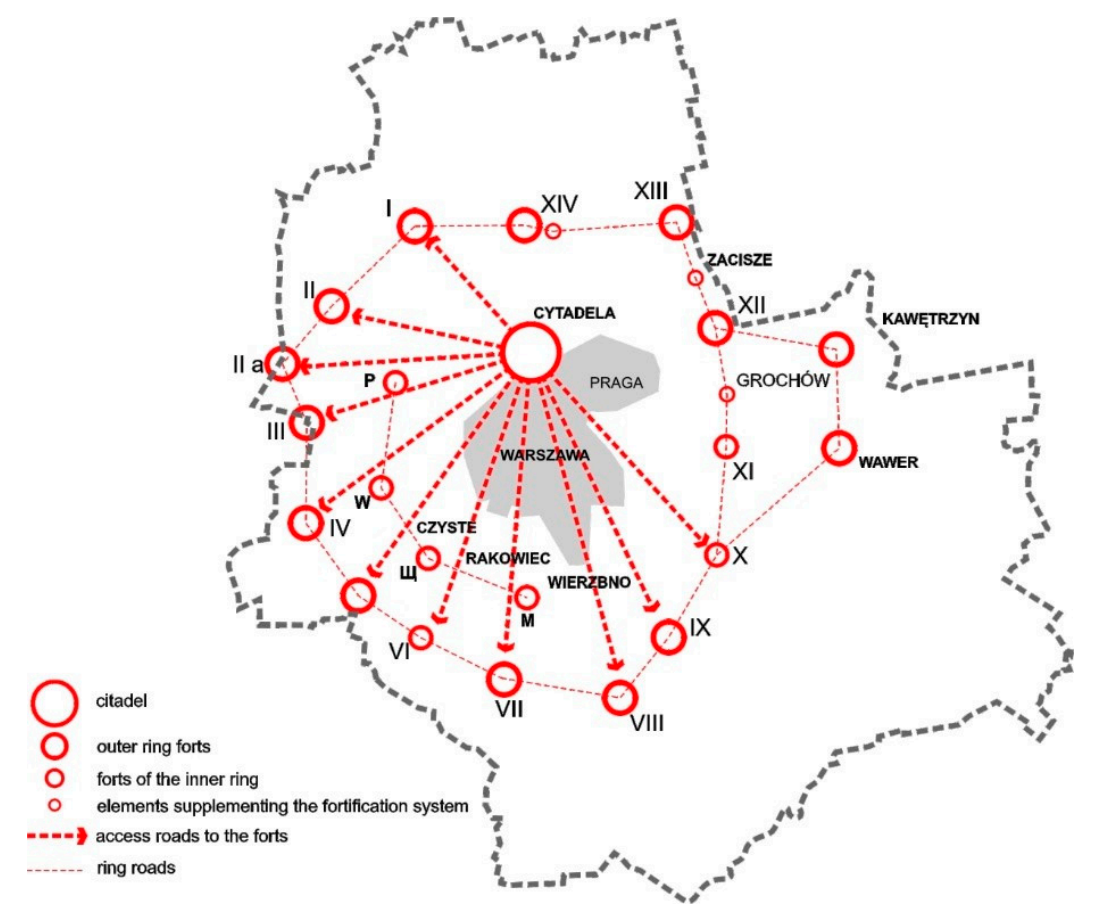

Figure 3. Diagram of the Warsaw Fortress (own study) Legend: 1: citadel; 2: Sokolnickiego "Siergiej” fort; 3: Tragutta „Aleksiej” fort; 4: Legionów Władimir” fort; 5: Śliwickiego (Jasińskiego) fort; 6: Bema forts (P-Parysów); 7: Szcza (Szczęśliwice) fort; 8: M-Mokotów fort; 9: Cze-Czernikaów fort; 10: I Bielany fort; 11: II Wawrzyszew fort, 12: Ila Babice fort; 13: III Blizne fort; 14: IV Chrzanów fort; 15: V Włochy fort; 16: VI Okęcie fort; 17: VII Zbarż fort; 18: VIIA Służewiec fort; 19: VIII Służew fort; 20: IX Czerniaków fort; 21: X Augustówka fort; 22: m XIII Lewiopol fort.

Fortress roads were necessary elements connecting the fortification rings. These roads can be divided into two types: rock roads and access roads. The rock roads connected the forts into rings, whereas the access roads connected the citadel directly with the forts. These were existing roads, adapted and modernized to perform new functions, as well as old ones. Radially running to the center of Warsaw and the citadel, today's main streets of Warsaw-Górczewska, Marymoncka, Puławska, Modlińska-are the adaptations of these connections. At the turn of the 1880s and 1890s, in order to strengthen the inner line, resistance points, a battery and inter-port embankments (total length of 15 $\mathrm{km}$ ) were built. These roads are also important communication routes in today's city structure [21].

It should be noted that due to such a structure and spatial division through streets, a relatively radial arrangement has been maintained until today, allowing use to now refer to the idea of $\mathrm{E}$. Howard's garden city. 
In the years 1892-1909, modernization and reconstruction of the fortification elements of the Warsaw Fortress were carried out. One of the main tasks was to strengthen the defense forces of the inter-fields in the necks of the left-bank forts (forts IV-VIII). As result, erected valleys with concrete traders were introduced. The infrastructure of the entire fortress was also expanded during this period. At the end of the 19th century, the Warsaw Fortress occupied an area of approximately twenty thousand ha, while the outer ring circumference is $48 \mathrm{~km}[7,23]$.

It can be assumed that the current avenues located near the forts of the Warsaw Fortress are former fortress roads. The fragmentary chestnut alleys are located along access roads, including Szczesliwice Fort, Fort A, and Fort IV and inside the Warsaw Citadel. Ash avenues were identified at Fort Służewiec and at the Warsaw Citadel, whereas maple avenues were planted along access roads to Fort M-Mokotów, Fort III, Fort V. Fragmentary oak alley systems were recognized at access roads to Fort IV, Fort P-Parysów and elm trees were found in Fort II. The best barbed wire was made of thorny black locust, which was also frequently planted for defensive purposes in Warsaw. A similar situation can be observed in the vicinity of Bielany Fort, now adjacent to the Bielański Forest Reserve. Shrub additions were usually used using native species, e.g., hawthorn, hornbeam, blackthorn, privet or apple trees. Blackberries, black and wild rose then were used to fill the gaps. They were thorny species, also acting as natural entanglements. Changing the rules of composition at the end of the 19th century for more chaotic and natural succession transformed the composition planned according to strict rules of symmetry into a random mass of planned vegetation and self-seeding, whose age can reach up to about 100 years (Figures 4-9).

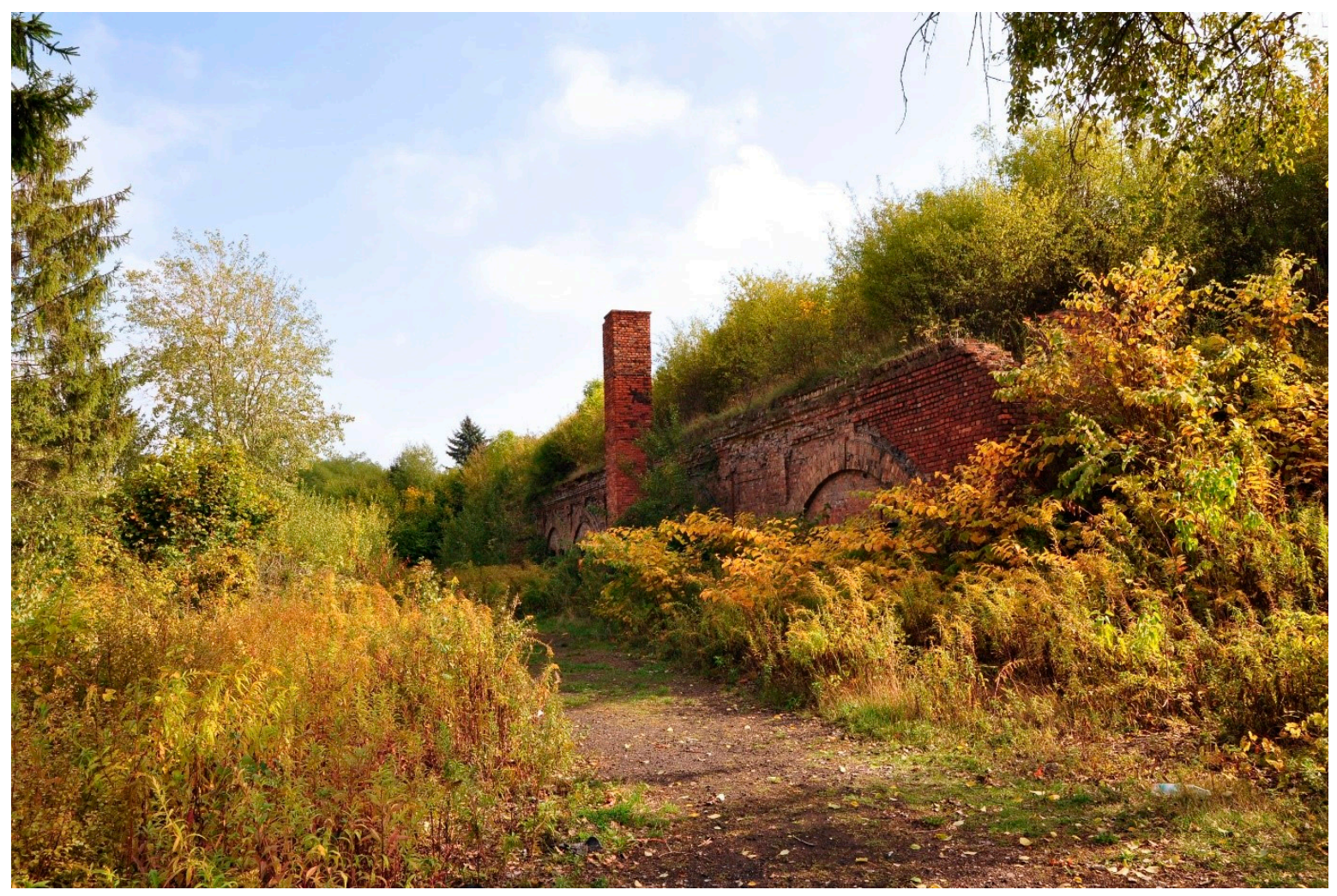

Figure 4. Szczesliwice Fort-unused area (Photo J. Botwina 9 October 2019). 


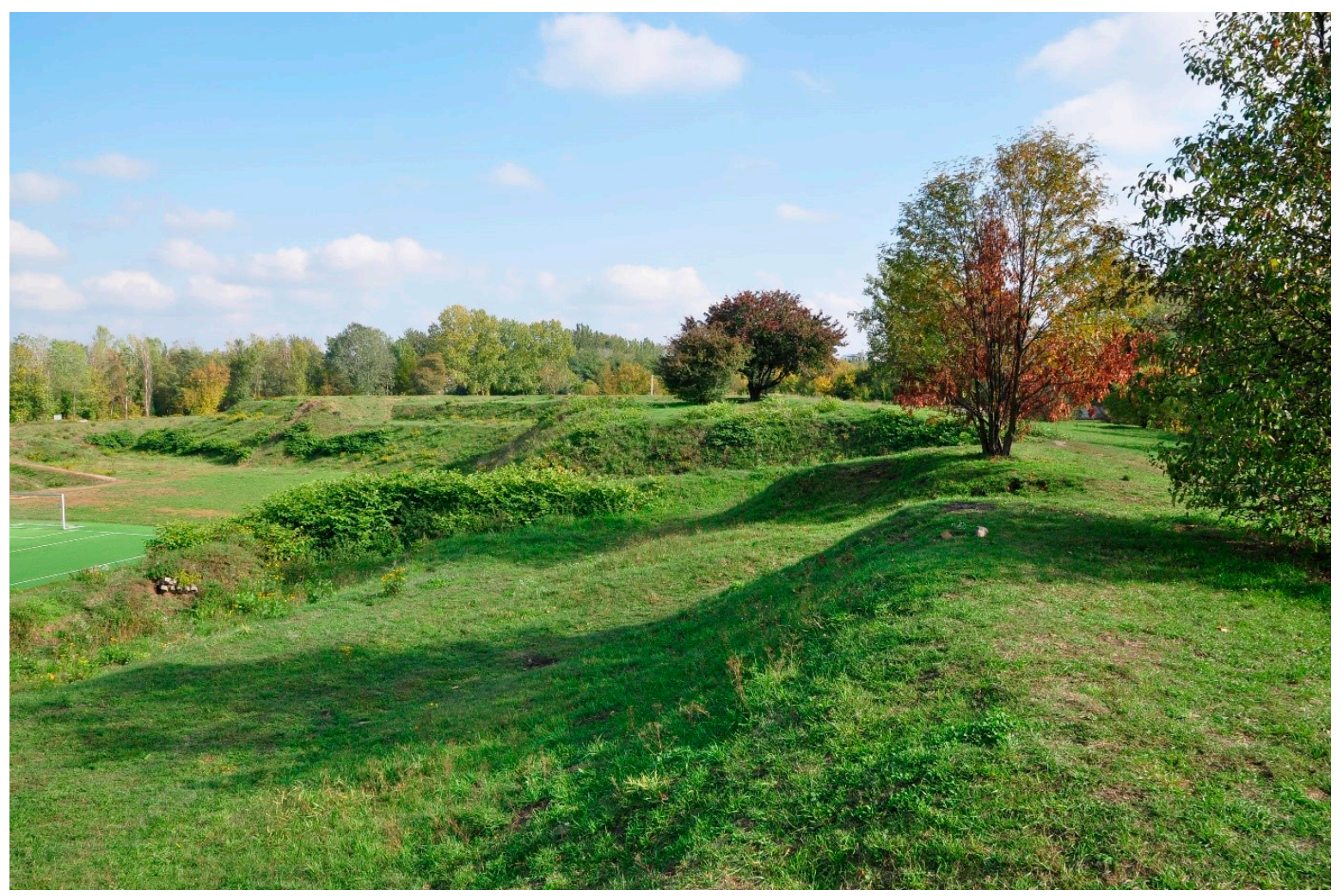

Figure 5. Włochy fort-city park (Photo. J. Botwina 9 October 2019).

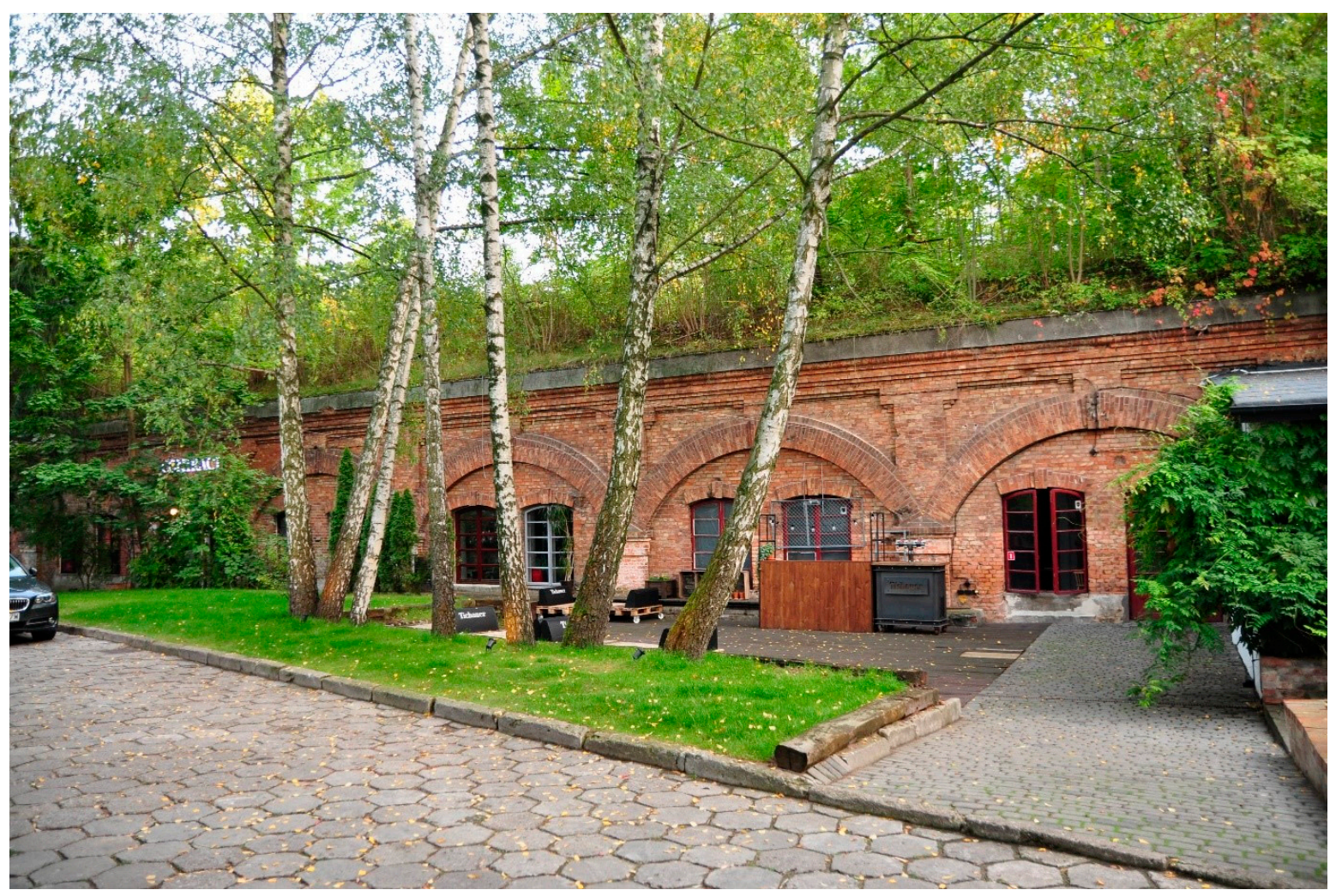

Figure 6. Mokotów Fort - service-oriented cultural use of old military buildings (Photo. J. Botwina 9 October 2019). 


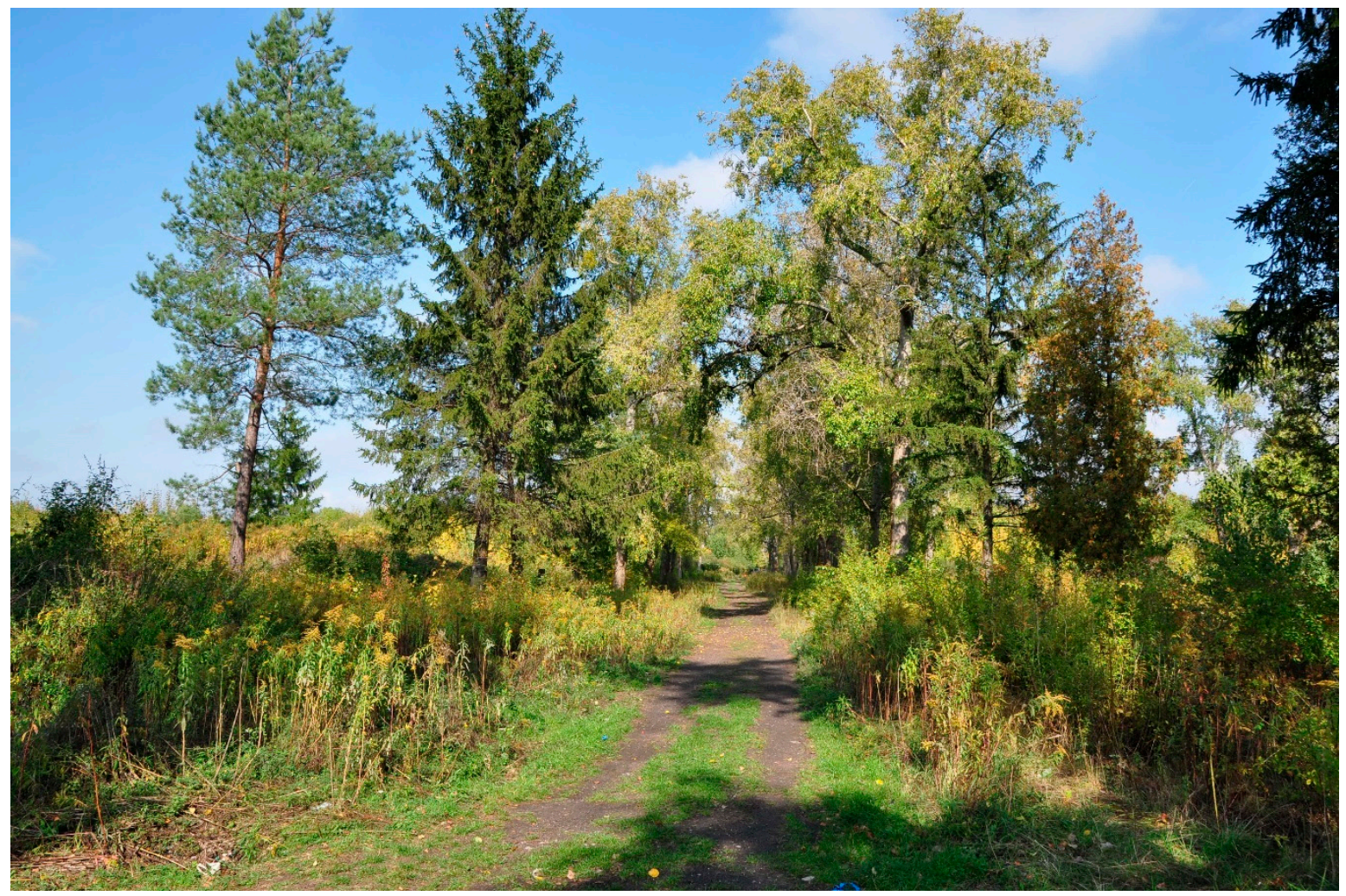

Figure 7. Remains of an old alley in Szczęśliwice Fort (Photo. J. Botwina 9 October 2019).

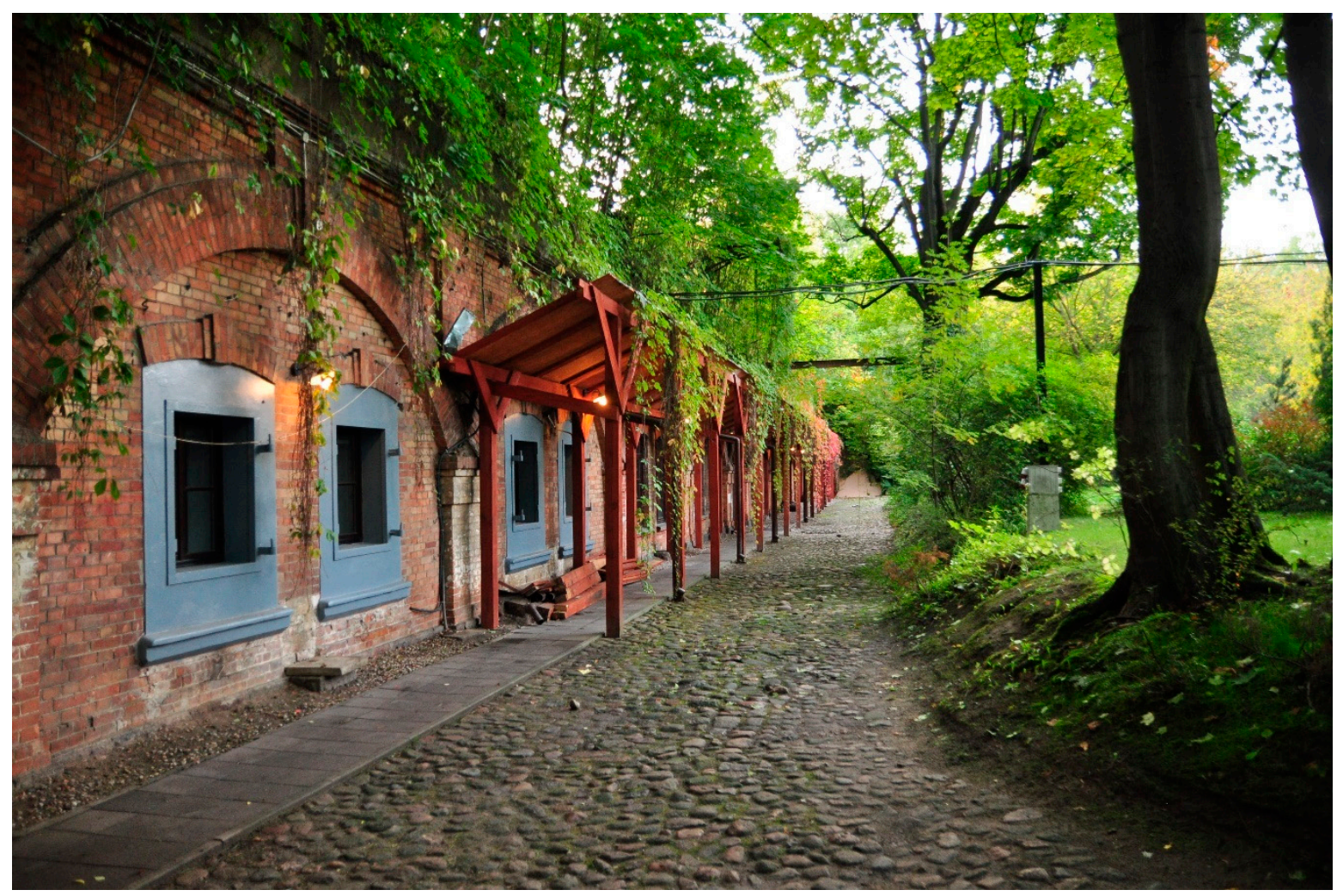

Figure 8. Fort buildings: Fort Mokotów (Photo. J. Botwina 9 October 2019). 


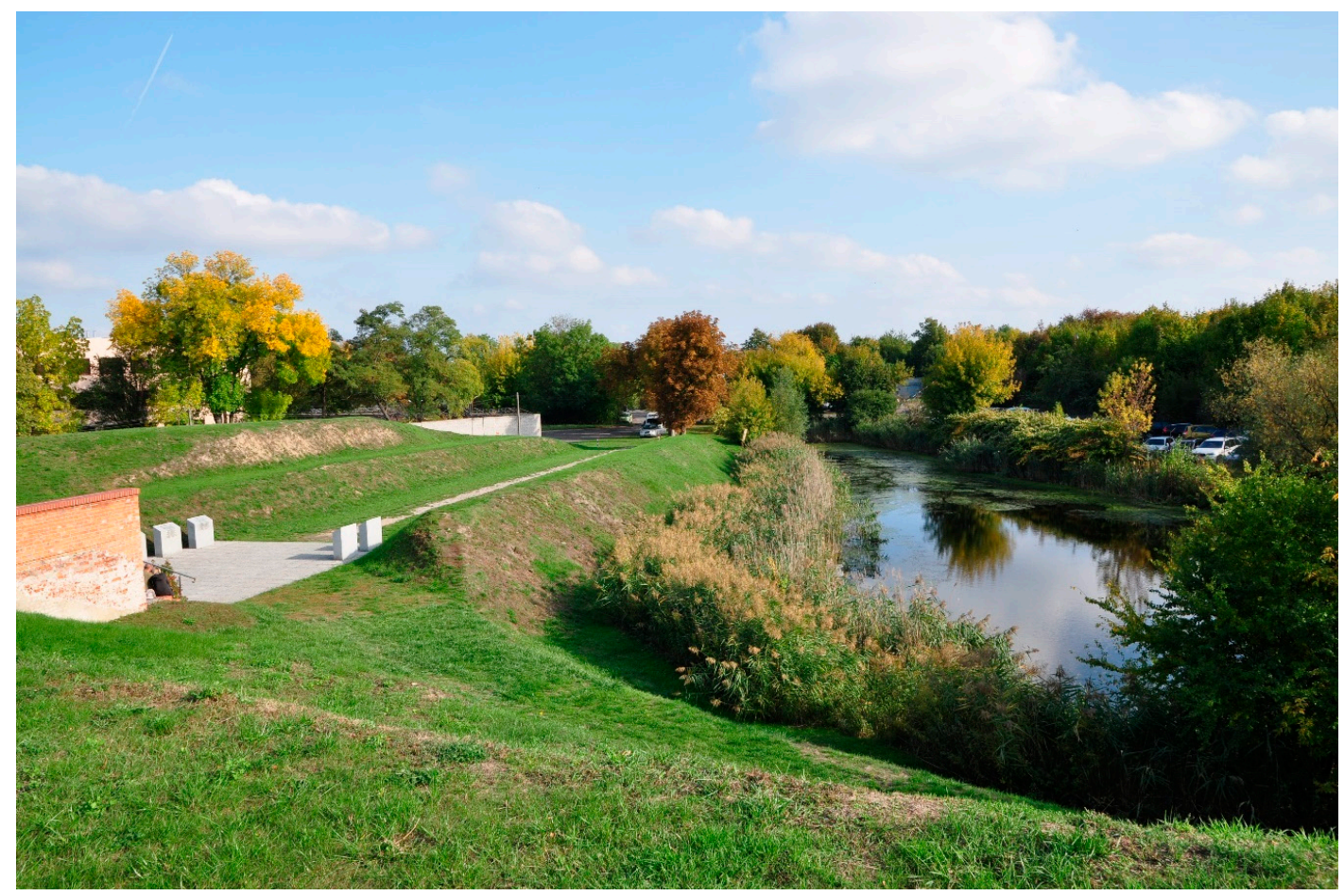

Figure 9. Moat Fort Okęcie (Photo. J. Botwina 9 October 2019).

According to the archival reports, the liquidation of cover trees on the ramparts of the Warsaw Citadel was carried out partly in the 1860s, during the reconstruction of the work. A similar phenomenon occurred at all modernized and rebuilt forts at the end of the 19th century [24]. Planting fast-growing trees in the late 19th and early 20th centuries covered most of the works of the Warsaw Fortress. It can currently be assumed that the plantings consisted of willows, birches and especially poplars. Nowadays, specific habitat conditions have developed in unused works and rare and often protected species of animals and plants have settled in them. Any actions that interfere with the plant structure often raise protests from ecological organizations. Another problem is performing logging operations without prior inventory, dendrochronological and historical research. This leads to the destruction of historic greenery or its successors and the inability to recreate the state from the turn of the 19th and 20th century. Fortifications of the Warsaw Fortress are located within them (Figure 4).

Due to the restructuring of the army as a result of system changes (1989), the Warsaw fortresses were handed over to the Military Property Agency and the Military Academy. Then, according to the law, some of the objects were put up for tenders. Nine forts have been communalized or privatized. The ignorance of the advantages and possibilities of using the Warsaw Fortress contributed to the degradation of a valuable relic of the Russian fortifications from the 19th and early 19th century. In addition, the loss of the military function of the fortress had a significant impact on Warsaw's physiognomy.

The spatial structure of the city during the 19th and early 20th centuries was heavily dependent on the Warsaw fortress. Until 1911, on the esplanade, all investments related to the erection of building facilities were significantly limited. In this way, the natural spatial development of the capital was stopped. The direct effects involved an increase in population density, space deformation, and increased concentration of buildings, resulting in a widespread housing deficit. The demand for investment areas also increased. The indirect effects included the thriving development of the towns that were located outside the wide fortress belt. Lifting of the abovementioned restrictions in 1911 caused a threefold administrative expansion of Warsaw in $1916[25,26]$ and the inclusion of the fortress facilities in the city's structure. Another problem was the connection of all post-fortified areas with the central part of the city (Figures 10-12). 


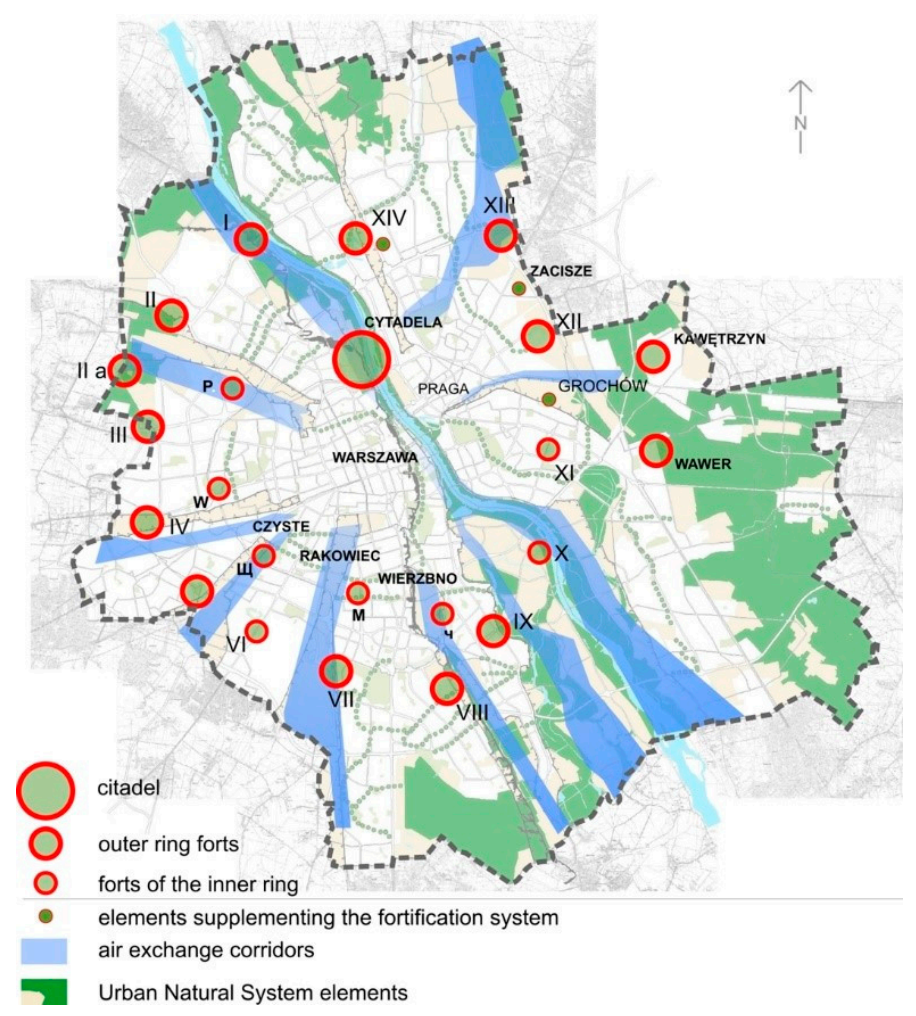

Figure 10. Aeration wedge system for the city with fortification rings (own calculation based on SUiKZP Warsaw).

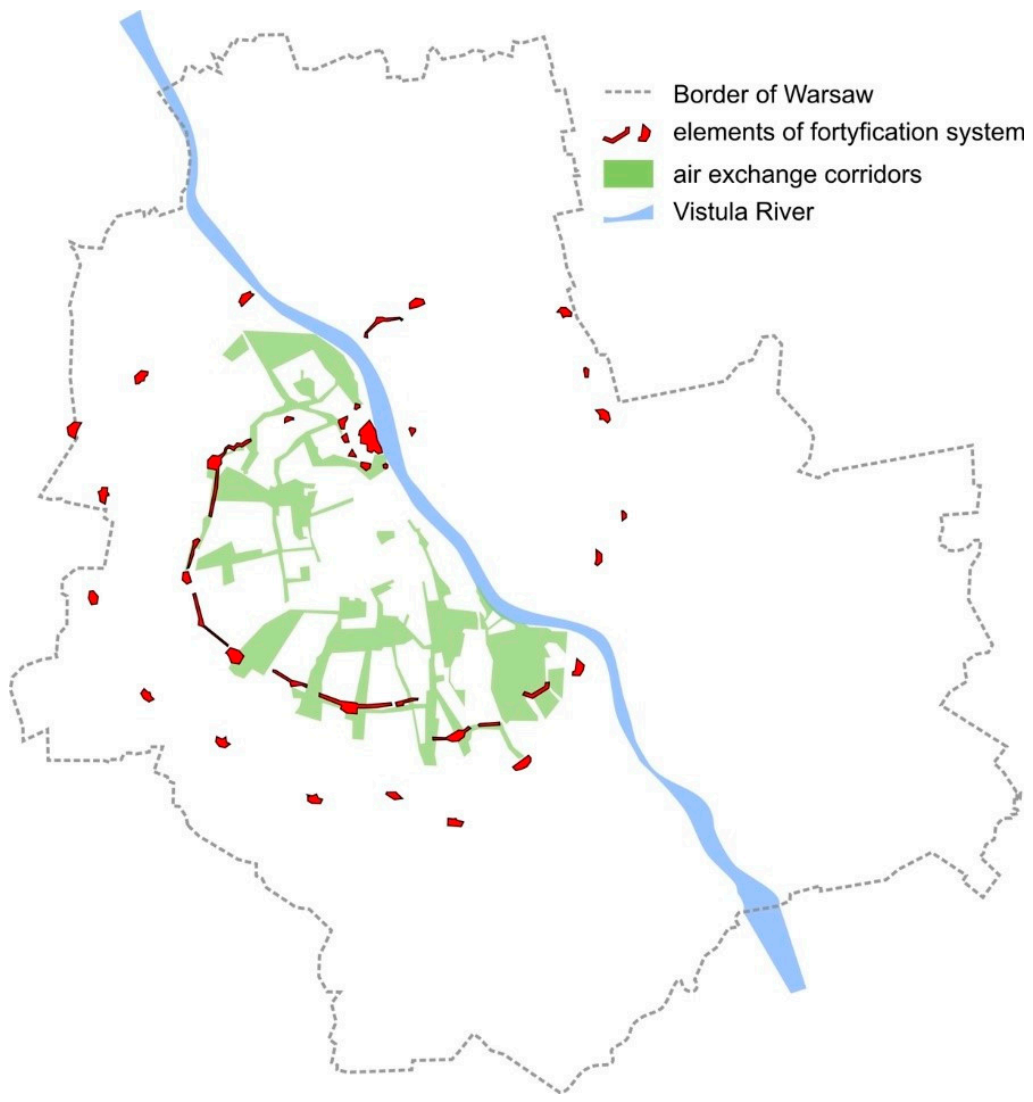

Figure 11. A system of ventilation wedges for the city with fortification rings (based on own design based on the Tołwiński project from 1933). 


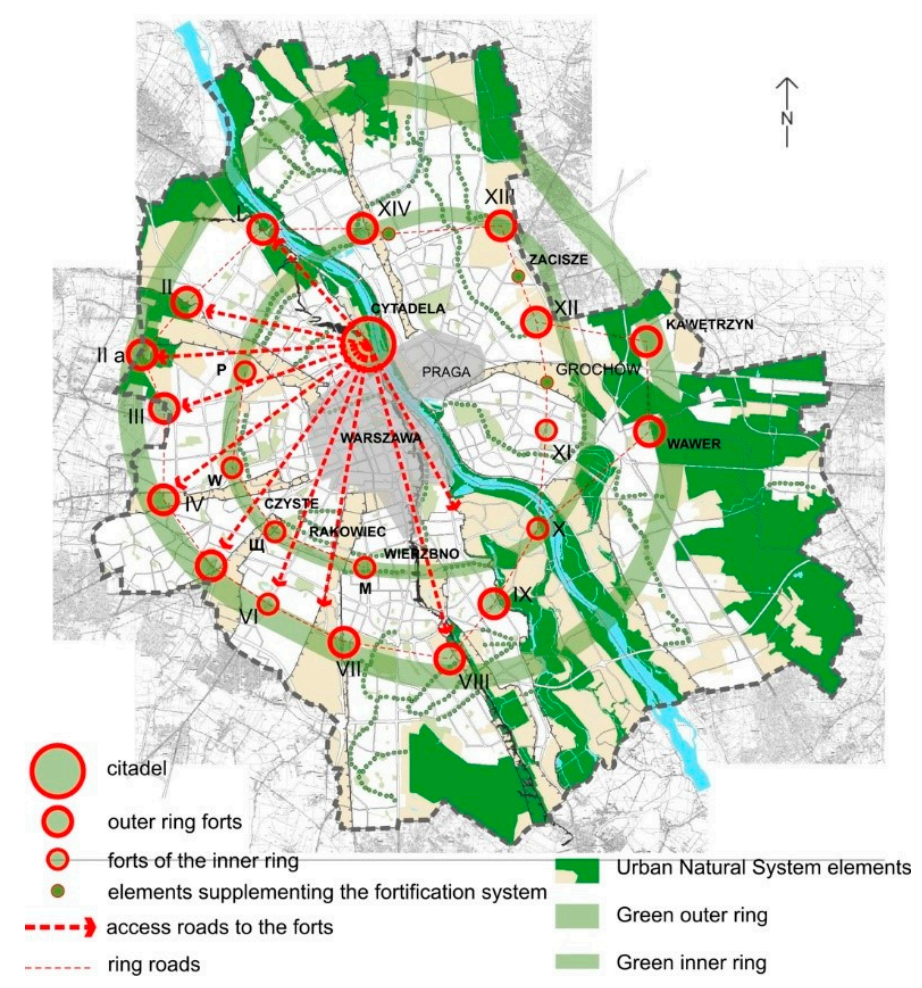

Figure 12. Fortification system of the Warsaw Fortress against the background of SPM-the city's natural system (based on the Urban Natural System map from SUiKZP Warsaw).

In 1918, post-fortress areas changed ownership. Although the owner-the Treasury-sold objects of the former fortress at a very low price or transferred them free of charge, the poor communication of these areas with the city center caused a slight interest from the population in buying these areas. The plan to solve this problem used the idea developed by E. Howard. In this way, numerous villa estates were created (including Żoliborz Oficerski, Czerniaków garden, Włochy garden), which centered around the forts. Thanks to this, Warsaw became a system of smaller garden-city units. New parks were also created around the forts (including Żeromski Park, Dreszer Park and Sowiński Park) [25]. The analysis of the spatial arrangement of Warsaw's weathering wedges clearly indicates that most of them are strongly structurally and spatially connected with the arrangement of forts.

In the interwar period, the idea of allotment gardens was extremely popular. In Warsaw such gardens were built around forts [27]. This was the beginning of the implementation of the so-called Great Warsaw (Figure 11).

Unfortunately, after the Second World War, previously developed urban planning guidelines were not binding. A departure from the urban plans of the Greater Warsaw missed the chance for a consistent development of the capital. The fortress was given to the army. During the Polish People's Republic, new random settlements were created in the fortress esplanade, diversified in urban and architectural terms for each of the districts (includingPrzyjaźń, Jelonki in Wola, Ksawerów, Służew, Służewiec and Sadyba housing estates). However, this was an inconsistent process without a comprehensive urban concept. This significantly contributed to the disharmony of Warsaw's landscape [28].

\subsection{Use of the Warsaw Fortress Objects and their Evaluation}

Of the 56 defensive facilities, only 33 have survived to this day. Objects that have not survived to this day were destroyed at different times. Some of them were demolished in the interwar period. However, most of them were demolished during World War II and directly in the post-war period. In their place, housing estates or other elements of urban infrastructure were created. At present, the area of the former fortress (nearly 250 ha of area, without protection zones), due to the size of the 
spatial layout, architecture, earth structures distinguished by the terrain in the background of the city landscape, is a very attractive element in the capital, whose potential can be taken into account in development projects.

The area of the Warsaw Fortress (city fortress), in contrast to the Kłodzko Fortress or the Srebrna Góra Fortress (mountain fortresses), apart from the large spatial dispersion, is characterized by intensive building activation, which is why the protection integrating fortification objects with the landscape is very difficult $[29,30]$.

The main source of the fortress's problems was the abolition of its most important function - the defense function. Both protection and management of these residues within the capital constitute a significant problem. The area occupied by the fortifications is 250 ha, which in 1995 accounted for over $1 \%$ of the invested areas, as well as nearly $17 \%$ of all the areas of services, administration and central functions of the capital [7,23].

On the basis of studies of source materials and field research, a compilation of elements of the Warsaw Fortress was made, in terms of availability, usage, degree of coverage of the plant cover, total area, preservation of historical matter, and suitability for recreation. The results are shown in Table 4 .

Table 4. Comparison of the land-use of the Warsaw Fortress forts.

\begin{tabular}{|c|c|c|c|c|c|c|c|}
\hline Location & Name & Access & Land-Use & $\begin{array}{c}\text { Coverage of } \\
\text { Woody } \\
\text { Vegetation (\%) }\end{array}$ & $\begin{array}{l}\text { Area } \\
\text { (ha) }\end{array}$ & $\begin{array}{c}\text { Conservation of } \\
\text { Historic } \\
\text { Substance (\%) }\end{array}$ & $\begin{array}{l}\text { The Usefulness of } \\
\text { the Fort in } \\
\text { Recreational Service }\end{array}$ \\
\hline \multirow{5}{*}{$\begin{array}{l}\text { The Citadel } \\
\text { Forts }\end{array}$} & Citadel & partly limited & city park, museum & 70 & 36 & 85 & Useful \\
\hline & Siergiej & without limits & & 70 & 0.1 & 60 & Useful \\
\hline & Aleksiej & without limits & city park & 70 & 0.1 & 85 & Useful \\
\hline & Władimir & without limits & & 70 & 0.1 & 85 & Useful \\
\hline & Sliwickiego & partly limited & apartment estate and park & 40 & 8 & 20 & Useful \\
\hline \multirow{4}{*}{$\begin{array}{l}\text { The inner } \\
\text { ring of forts }\end{array}$} & P-Parysów & without limits & city park, sport & 70 & 8 & 80 & Useful \\
\hline & Szcze-Szczęśliwice & without limits & wasteland & 50 & 7 & 50 & Useful \\
\hline & M-Mokotów & without limits & clubs & 60 & 7 & 65 & Useful \\
\hline & Cze-Czerniaków & without limits & wasteland & 60 & 7 & 70 & Useful \\
\hline \multirow{13}{*}{$\begin{array}{l}\text { The outer } \\
\text { ring of forts }\end{array}$} & I Bielany & without limits & city park & 50 & 8 & 35 & Useful \\
\hline & II Wawrzyszew & partly limited & allotments & 40 & 6 & 65 & Useful \\
\hline & IIA Babice & closed & military object & 60 & 5 & 70 & not useful \\
\hline & III Blizne & partly limited & clubs and wasteland & 40 & 5 & 60 & Useful \\
\hline & IV Chrzanów & without limits & paintball & 60 & 5 & 80 & Useful \\
\hline & V Włochy & partly limited & $\begin{array}{l}\text { Institute of Nuclear } \\
\text { Chemistry, bike cross }\end{array}$ & 40 & 5 & 65 & partly useful \\
\hline & VI Okęcie & partly limited & storage area, parking & 20 & 5 & 50 & not useful \\
\hline & VII Zbarż & partly limited & wasteland & 60 & 5 & 40 & not useful \\
\hline & VIIA Służewiec & partly limited & $\begin{array}{l}\text { film production company } \\
\text { "Czołówka" }\end{array}$ & 60 & 3 & 70 & not useful \\
\hline & VIII Służew & $\begin{array}{c}\text { partly limited } \\
\text { banned from parts }\end{array}$ & apartment estate and park & 40 & 7 & 65 & partly useful \\
\hline & IX Czerniaków & $\begin{array}{l}\text { of the fort, because } \\
\text { there are } \\
\text { unexploded }\end{array}$ & $\begin{array}{l}\text { city park and museum, } \\
\text { partly military object }\end{array}$ & 50 & 7 & 50 & Useful \\
\hline & X Augustówka & without limits & Sport & 5 & 5 & 30 & Useful \\
\hline & XIII Lewiopol & Closed & military object & 60 & 5 & 5 & not useful \\
\hline
\end{tabular}

The analysis of the test results indicates that out of 22 analyzed objects, the majority (17 objects) can be used for recreational purposes. Objects described as unusable are currently excluded from recreational use because of the limited or unavailable access to them, e.g., a military unit or wasteland. It should be noted, however, that the area of each of these facilities is largely covered with vegetation and is characterized by a very high coefficient of biologically active area. Canopy coverage can reach as much as $70 \%$. The share of historic architectural matter is also significant, reaching up to $85 \%$ of the area. It includes barrack buildings and other elements of the defensive work, such as a battle slope (plateau, glacis), positions, moat, embankments, shelters, artillery and infantry fire positions, warehouses, observation and artillery towers, etc. The results of WNET analysis and others research data are presented in the Tables 5 and 6 and Figure 13. 
Table 5. WNET analysis results.

\begin{tabular}{|c|c|c|c|c|c|}
\hline NR & Plant Cover & Water & $\begin{array}{l}\text { Degree of } \\
\text { Land Use }\end{array}$ & $\begin{array}{l}\text { Landscape } \\
\text { Protection }\end{array}$ & Sum \\
\hline 1. Citadel & 2 & 1 & 2 & 1 & 6 \\
\hline 2. Sokolnickiego "Siergiej"Fort & 2 & 1 & 2 & 1 & 6 \\
\hline 3. Tragutta "Aleksiej" Fort & 1 & 0 & 2 & 1 & 4 \\
\hline 4. Legionów "Władimir" Fort & 1 & 0 & 2 & 1 & 4 \\
\hline 5. Śliwickiego (Jasińskiego) Fort & 2 & 0 & 1 & 1 & 4 \\
\hline 6. forty Bema (P-Parysów) Fort & 2 & 2 & 2 & 1 & 7 \\
\hline 7. Szcza (Szczęśliwice) Fort & 2 & 0 & 1 & 0 & 3 \\
\hline 8. M-Mokotów Fort & 2 & 1 & 2 & 1 & 6 \\
\hline 9. Cze - Czerniaków Fort & 2 & 1 & 1 & 1 & 5 \\
\hline 10. I Bielany Fort & 2 & 0 & 1 & 0 & 3 \\
\hline 11. II Wawrzyszew Fort & 2 & 2 & 1 & 1 & 6 \\
\hline 12. IIa Babice Fort & 2 & 2 & 0 & 0 & 4 \\
\hline 13. III Blizne Fort & 2 & 2 & 1 & 0 & 5 \\
\hline 14. IV Chrzanów Fort & 1 & 1 & 1 & 1 & 4 \\
\hline 15. V Włochy Fort & 2 & 0 & 2 & 1 & 5 \\
\hline 16. VI Okęcie Fort & 2 & 2 & 2 & 1 & 7 \\
\hline 17. VII Zbarż Fort & 2 & 2 & 1 & 0 & 5 \\
\hline 18. VIIA Służewiec Fort & 2 & 1 & 1 & 1 & 5 \\
\hline 19. VIII Służew Fort & 2 & 0 & 2 & 1 & 5 \\
\hline 20. IX Czerniaków Fort & 2 & 2 & 2 & 1 & 7 \\
\hline 21. X Augustówka Fort & 2 & 0 & 2 & 0 & 4 \\
\hline 22. XIII Lewiopol & 2 & 0 & 0 & 0 & 2 \\
\hline Average & 1,863636 & 0,909091 & 1,409091 & 0,681818 & \\
\hline
\end{tabular}

Table 6. Results of the cultural landscape assessment.

\begin{tabular}{ccccccccccccccccccccccc}
\hline Criterion & $\mathbf{1}$ & $\mathbf{2}$ & $\mathbf{3}$ & $\mathbf{4}$ & $\mathbf{5}$ & $\mathbf{6}$ & $\mathbf{7}$ & $\mathbf{8}$ & $\mathbf{9}$ & $\mathbf{1 0}$ & $\mathbf{1 1}$ & $\mathbf{1 2}$ & $\mathbf{1 3}$ & $\mathbf{1 4}$ & $\mathbf{1 5}$ & $\mathbf{1 6}$ & $\mathbf{1 7}$ & $\mathbf{1 8}$ & $\mathbf{1 9}$ & $\mathbf{2 0}$ & $\mathbf{2 1}$ & $\mathbf{2 2}$ \\
\hline antiquity & 2 & 2 & 2 & 2 & 2 & 2 & 2 & 2 & 2 & 2 & 2 & 2 & 2 & 2 & 2 & 2 & 2 & 2 & 2 & 2 & 2 & 2 \\
historicity & 3 & 3 & 3 & 3 & 3 & 3 & 3 & 3 & 3 & 3 & 3 & 3 & 3 & 3 & 3 & 3 & 3 & 3 & 3 & 3 & 3 & 3 \\
authenticity & 3 & 3 & 2 & 3 & 2 & 3 & 3 & 3 & 2 & 1 & 2 & 2 & 2 & 2 & 3 & 3 & 3 & 3 & 3 & 3 & 2 & 2 \\
aesthetic value & 3 & 3 & 3 & 3 & 2 & 3 & 2 & 2 & 2 & 2 & 2 & 2 & 2 & 2 & 3 & 2 & 3 & 3 & 3 & 3 & 2 & 2 \\
Harmony & 3 & 3 & 3 & 3 & 1 & 3 & 2 & 3 & 2 & 2 & 3 & 3 & 3 & 2 & 3 & 2 & 3 & 3 & 3 & 3 & 2 & 2 \\
uniqueness & 3 & 3 & 3 & 3 & 2 & 3 & 3 & 3 & 3 & 3 & 3 & 3 & 3 & 3 & 3 & 3 & 3 & 3 & 3 & 3 & 2 & 2 \\
emotional value & 3 & 3 & 3 & 3 & 2 & 3 & 2 & 3 & 3 & 2 & 3 & 3 & 3 & 2 & 3 & 2 & 3 & 3 & 3 & 3 & 3 & 2 \\
value in use & 3 & 3 & 3 & 3 & 1 & 3 & 2 & 2 & 3 & 2 & 2 & 1 & 2 & 2 & 3 & 2 & 3 & 3 & 3 & 3 & 2 & 2 \\
Sum & 23 & 23 & 22 & 23 & 15 & 23 & 19 & 21 & 20 & 17 & 20 & 19 & 20 & 18 & 23 & 19 & 23 & 23 & 23 & 23 & 18 & 17 \\
\hline
\end{tabular}

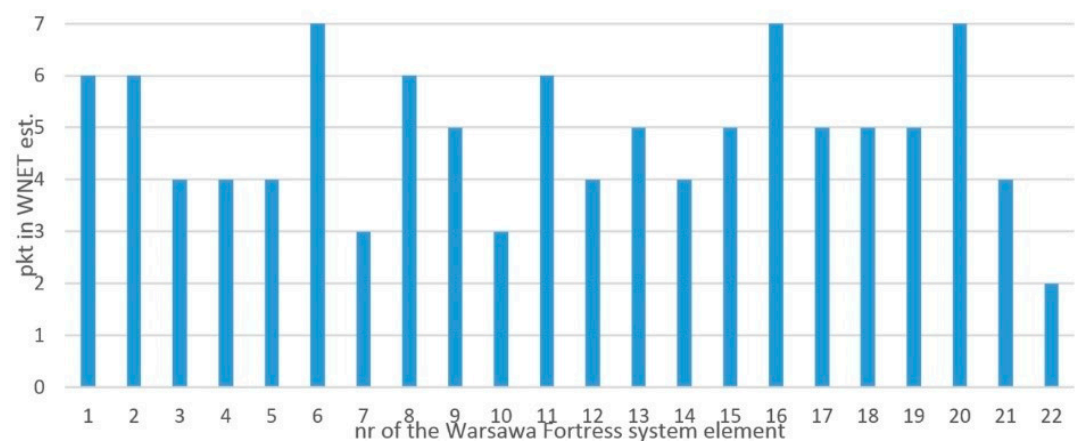

Figure 13. Warsaw Fortress-comparison of the obtained assessment of individual elements of the fortress landscape system in the WNET method. Legend: 1: citadel; 2: Sokolnickiego "Siergiej" Fort; 3: Tragutta "Aleksiej" Fort; 4: Legionów "Władimir" Fort; 5: Śliwickiego (Jasińskiego) Fort; 6: Bema (P-Parysów) Fort; 7: Szcza (Szczęśliwice) Fort; 8: M-Mokotów Fort; 9: Cze - Czernikaów Fort; 10: I Bielany Fort; 11: II Wawrzyszew Fort, 12: IIa Babice Fort; 13: III Blizne Fort; 14: IV Chrzanów Fort; 15: V Włochy Fort; 16: VI Okęcie Fort; 17: VII Zbarż Fort; 18: VIIA Służewiec Fort; 19: VIII Służew Fort; 20: IX Czerniaków Fort; 21: X Augustówka Fort; 22: XIII Lewiopol Fort. 
With an average of 4.86 points and a maximum score of 7 points, it can be concluded that the examined objects obtained a very high landscape value, of the order of $70 \%$ of the maximum mark.

Assessment of the cultural landscape according to adopted criteria [21].

All the objects mentioned above have received very high marks. Their average value is 20.59 points (Figure 14). The minimum mark is seven points, while the maximum one is 24 points. The Śliwicki Fort had the lowest rating, which was mainly due to the fact that its architecture is in a very poor condition, and the whole layout was disturbed by the construction of a housing estate in the fort and its foreground.

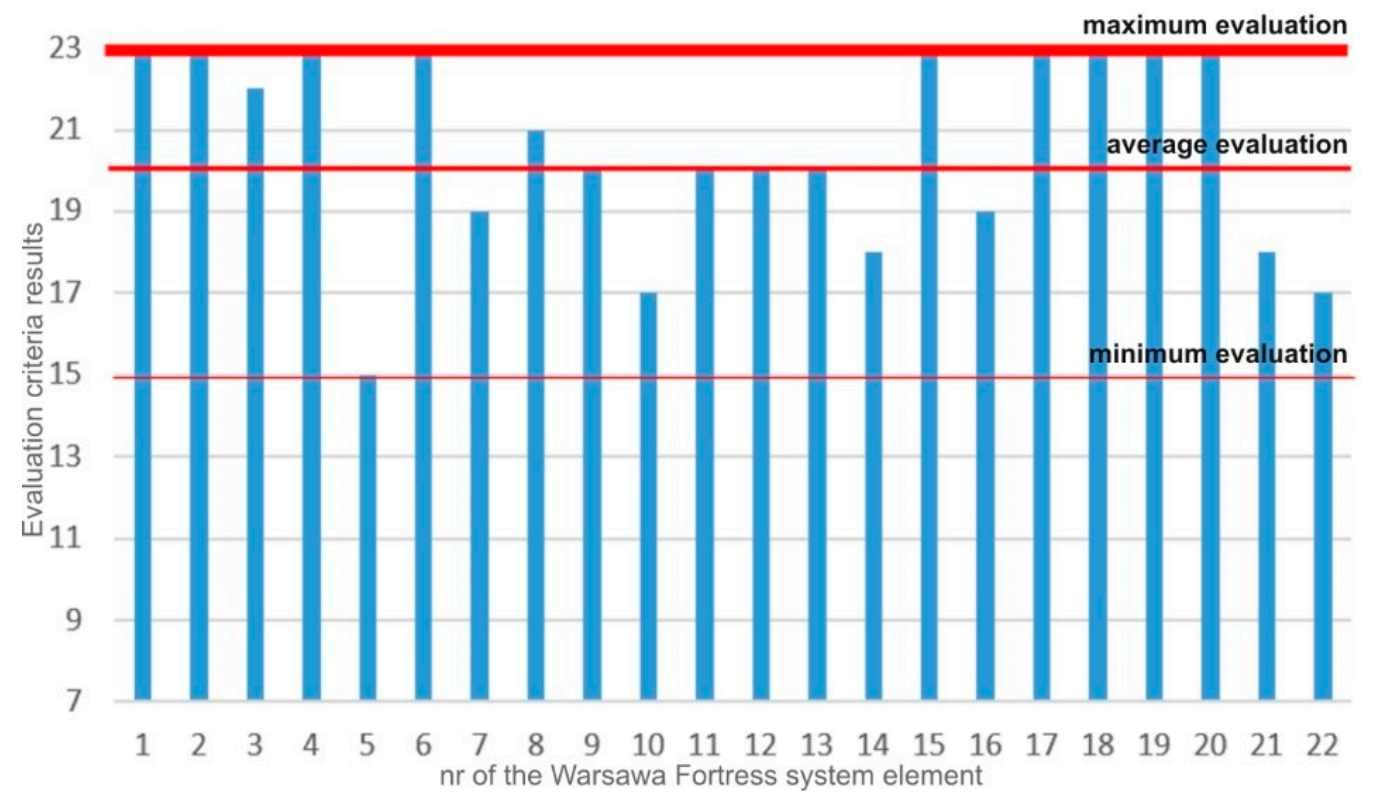

Figure 14. Results of the cultural landscape assessment. Legend: 1: citadel; 2: fSokolnickiego "Siergiej" Fort; 3: Tragutta "Aleksiej" Fort; 4: Legionów "Władimir" Fort; 5: Śliwickiego (Jasińskiego) Fort; 6: Bema (P-Parysów) Fort; 7: Szcza (Szczęśliwice) Fort; 8: M-Mokotów Fort; 9: Cze - Czernikaów Fort; 10: I Bielany Fort; 11: II Wawrzyszew Fort, 12: IIa Babice Fort; 13: III Blizne Fort; 14: IV Chrzanów Fort; 15: V Włochy Fort; 16: VI Okęcie Fort; 17: VII Zbarż Fort; 18: VIIA Służewiec Fort; 19: VIII Służew Fort; 20: IX Czerniaków Fort; 21: X Augustówka Fort; 22: XIII Lewiopol Fort.

On the other hand, the high share of historical buildings and vegetation as well as good accessibility (Table 1) are the reason why the average rating is so high.

This criterion is assessed uniformly for the entire facility due to the time of creation of all elements of the Warsaw Fortress. The same applies to the next two criteria: historicity and authenticity. Individual defensive works are characterized by very high values of historicity. A program related to qualified military tourism can be implemented in each of the facilities or at low cost. Historic events are organized within the forts.

Harmony is closely connected with the three previously analyzed criterion, somehow being their outcome. Also, in this category, the examined objects show a very high rating.

All elements of the Warsaw Fortress system were highly rated for their uniqueness and aesthetics. Apart from the unique architectural form, the original relief of the area contributed to this. This also applies to the objects that are partially devastated or used randomly. The unique value is the shape of the ramparts and the fortress buildings to various degrees. Often, due to its originality, there are gastronomy, artistic, exhibition or museum functions which had an impact on the attractiveness rating.

The average emotional value of the examined objects was rated as being very high, amounting to 2.73. The emotional attitude to the studied objects is presented in the PCA analysis and Pearson correlation.

For PCA analysis, gender and education were combined, determining: 
FW-women with higher education

FS-women with secondary education

FZ-women with vocational education

MW-men with higher education

MS - men with secondary education

MZ-men with vocational education

The first factor, with the highest impact (68.96\%), apparently shows the respondents' personal attitude towards forts, showing their positive perception and increased knowledge. This ratio is inversely proportional to age (Figure 15).

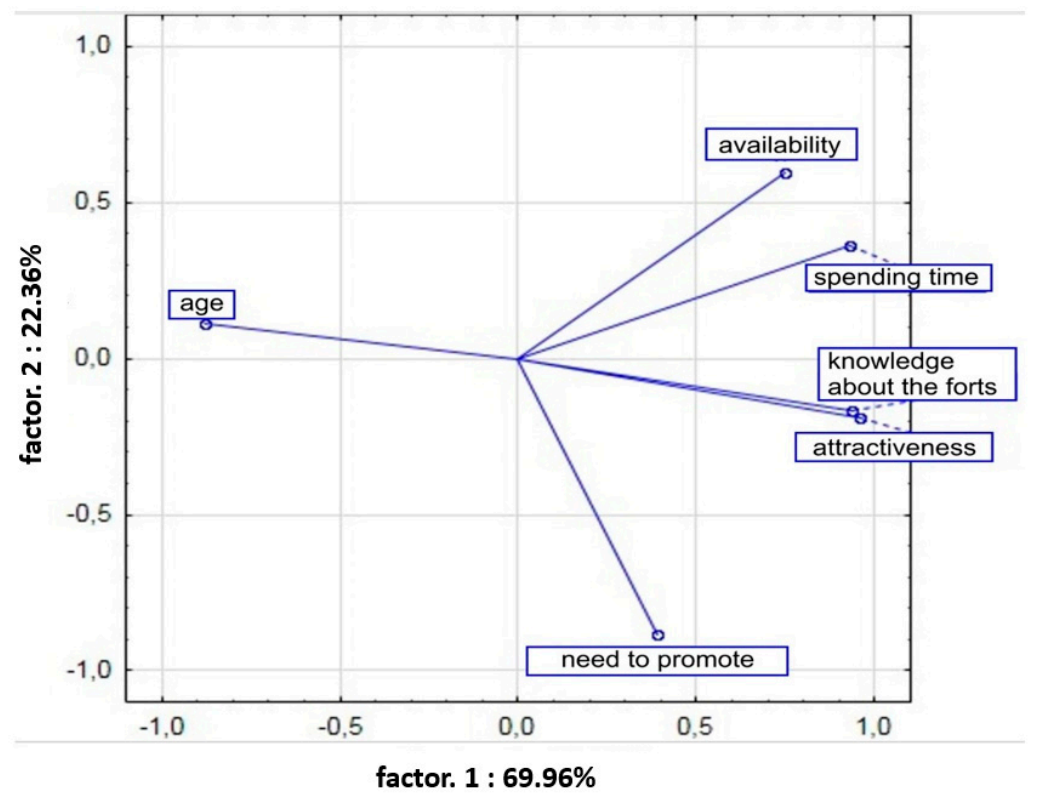

Figure 15. Variable projection on factor plane-PCA analysis results.

The second factor is related to the availability of forts and the awareness of their existence in general; respondents note that forts that are not easily accessible need more publicity. Spending time in forts is more related to their availability (the axis of spending time is closer to the axis of accessibility), than to attractiveness, but the latter is also not without significance.

In regards to the previous figure, highly educated respondents constituted the group which was most interested in forts. It can also be said that they have the greatest knowledge on this subject. Men with a secondary education also appreciate forts. Women with secondary and vocational education are least interested in them (the position of the groups is geometrically projected on the $X$ axis).

For women with a secondary education, the availability of forts is a more important criterion than their essence.

However, the conducted research shows that women and men with vocational education are not interested in forts as such. Moreover, their availability does not matter to them-they are on the opposite side of the quadrant, in which a simple correlation develops: "I spend time" on the variable projection chart (Figure 16). 


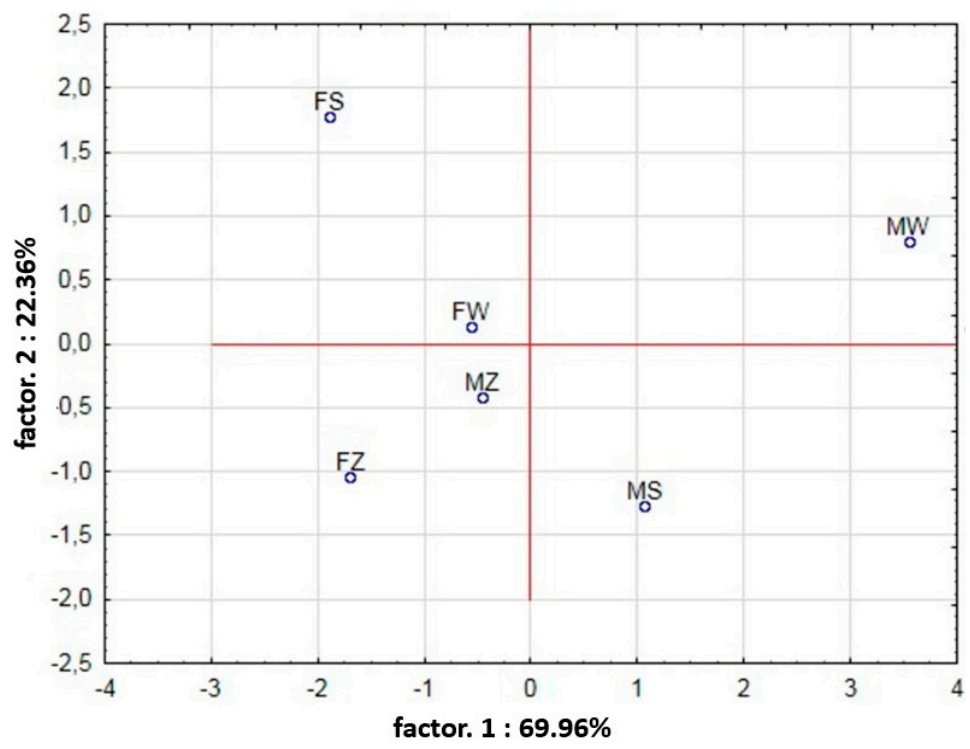

Figure 16. Case plan view on the factor plane-PCA analysis result. The projection of cases on the plane of factors $(1 \times 2)$, Cases of the sum of the squares $>+0,00$, Labels: Ages/education.

As a result of the survey (Table 7), it turned out that the attractiveness of the fortified objects is correlated with the gender and age of visitors. In this case, men showed more interest in forts than women. However, in the women's group, over $66 \%$ of the respondents also positively assessed the attractiveness of the fortress buildings. Interesting information was obtained by analyzing the dependence between the age of the surveyed people and the assessment of the attractiveness of the objects. Unexpectedly, it turned out that attractiveness of such objects grew with age: the group of 30-34-year olds indicated the highest perceived attractiveness of the objects (Figure 17).

Table 7. The value of linear correlation coefficients ( $r$ ) between individual respondents' features and the responses given in the survey.

\begin{tabular}{cccccccc}
\hline Linear Correlation & Education & Age & Question 1 & Question 2 & Question 3 & Question 4 & Question 5 \\
\hline Sex & $0.21^{*}$ & -0.01 & $0.25^{*}$ & 0.9 & 0.15 & 0.14 & 0.06 \\
Education & & 0.09 & -0.10 & -0.12 & -0.11 & -0.18 & -0.15 \\
Age & & & $-0.21^{*}$ & -0.01 & -0.15 & 0.15 & $0.62^{* *}$ \\
question 1 & & & & 0.02 & $0.79^{* *}$ & -0.09 & -0.08 \\
question 2 & & & & & 0.02 & $0.56^{* *}$ \\
question 3 & & & & & & $0.32^{* *}$ \\
question 4 & & & & & & \\
\hline
\end{tabular}

Explanations: $\mathrm{n}=198 ;{ }^{*} \mathrm{r} 0.05=0.195 ;{ }^{* *} \mathrm{r} 0.01=0.254$

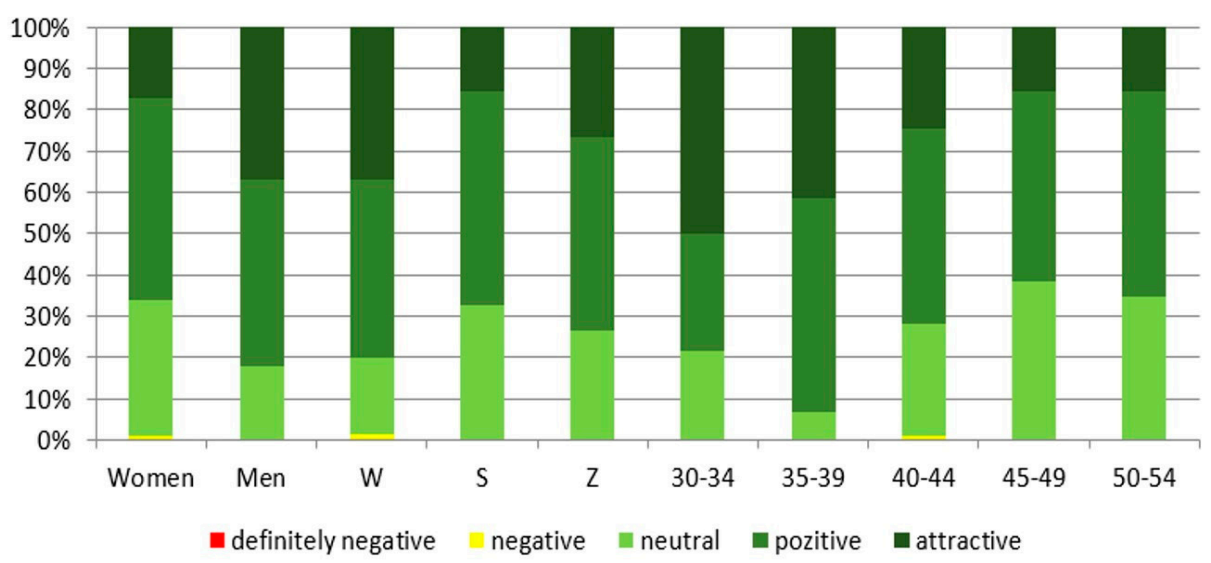

Figure 17. Attractiveness of fortified buildings based on the opinion of respondents (\%). 
While analyzing the obtained answers, it can be stated that people with higher education levels assessed fortifications more highly in terms of their attractiveness. However, education did not determine the answer to the question about the attractiveness of objects. Moreover, the respondents' knowledge of objects strongly correlated with the positive assessment of the attractiveness of the above-mentioned objects $\left(\mathrm{r}=0.79^{* *}\right)$. Men turned out to be a group which had a greater knowledge of history (over $80 \%$ ). On the other hand, slightly fewer women $(69 \%)$ knew the history of the fortifications (Figure 18).

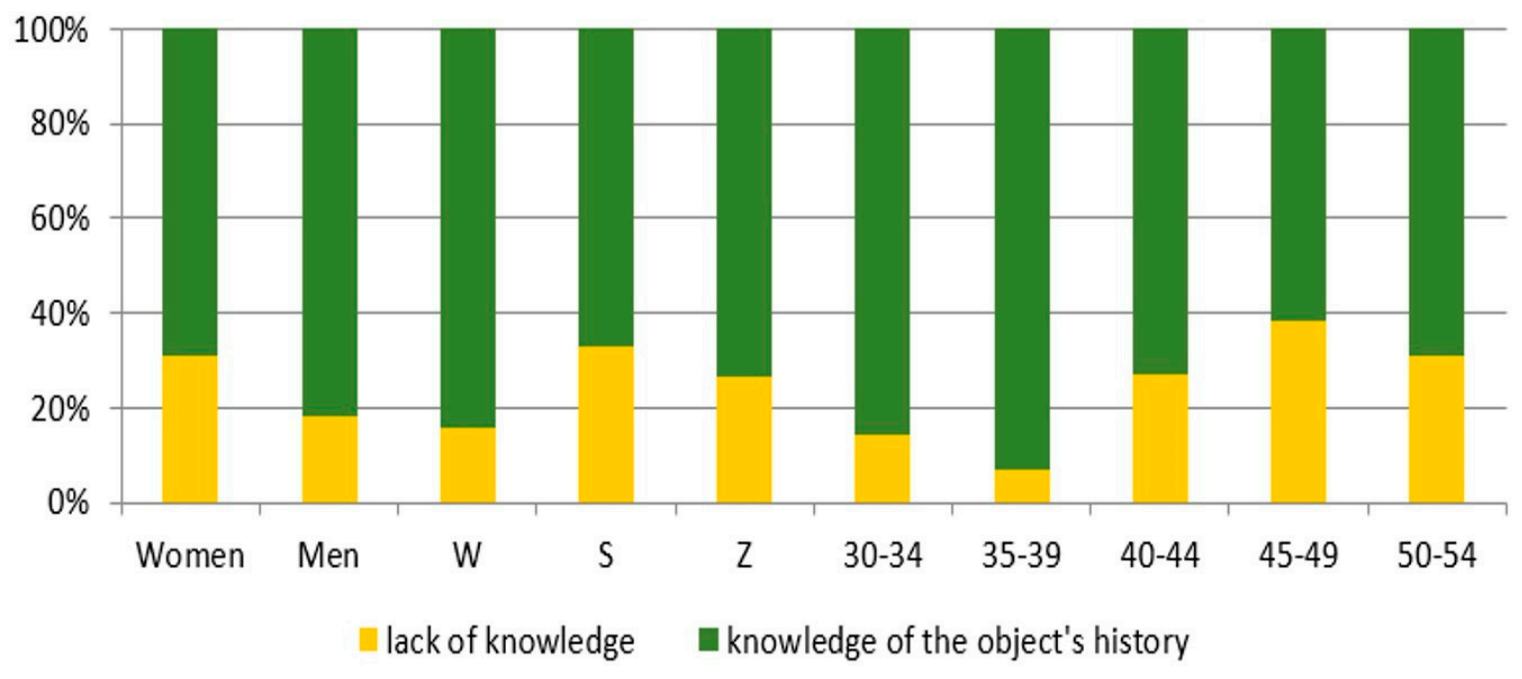

Figure 18. Knowledge about the fortress (\%).

In general, we can say that regardless of their education or age group, respondents were characterized by a large knowledge about the history of objects, with an average of over $60 \%$ of positive responses. The 30-year-olds (30-34 years) group deserve special attention, as this group included over $92 \%$ of those who were interested in the history of such objects. Unexpectedly, the elderly (40-45 years old) knew several historical events that took place in the forts. The attractiveness of the objects in the fort also significantly affects the frequency of visits $(r=0.62 * *)$. Also, knowledge of these objects determines the number of visitors $\left(r=0.56^{* *}\right)$ the fort receives. In this case, men are more likely to visit fortifications, with the age group of 30-year-olds being particularly dominant here. The education of the respondents did not determine the frequency of visits to the fortress (Figure 19).

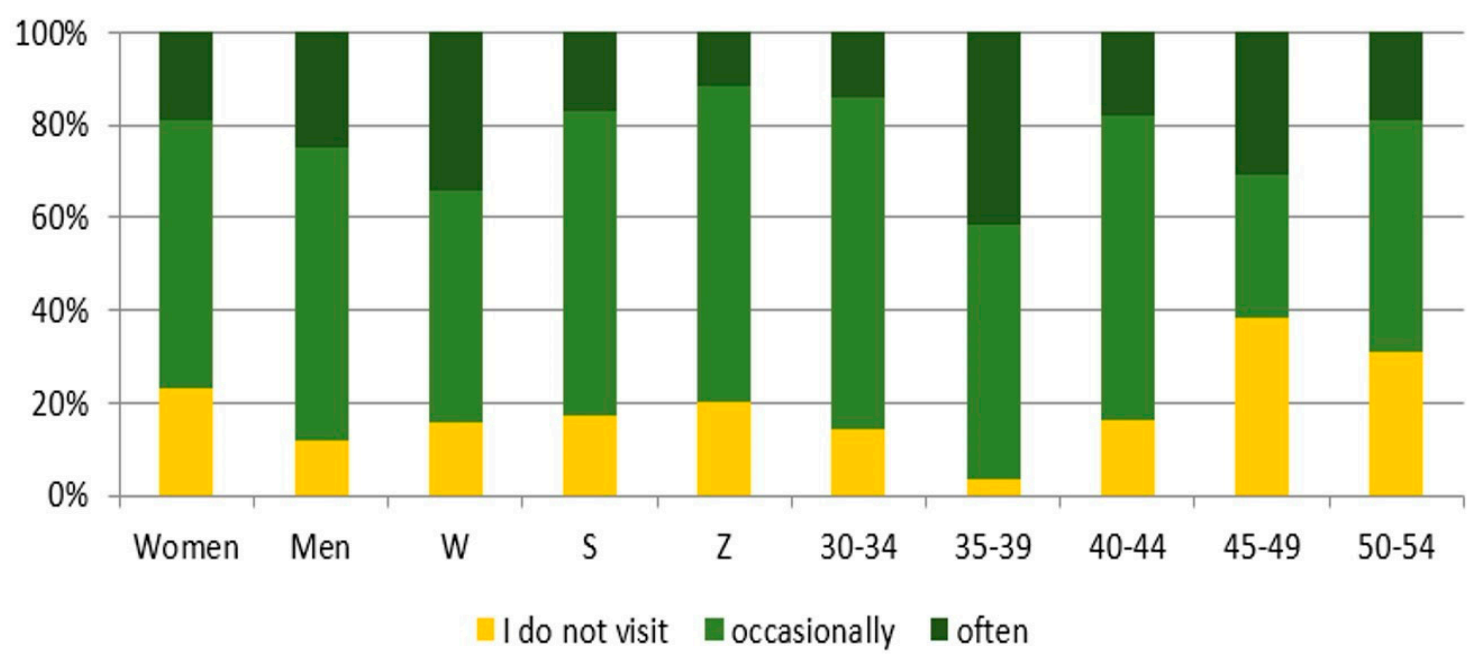

Figure 19. Frequency of visits in fortified buildings by respondents (\%). 
Respondents indicated a great need to promote historical objects. Despite the visitors' great knowledge, they still indicated the need for promotion and easier accessibility to such objects (Figures 20 and 21). Only in the group of 30-34-year old, who showed the greatest interest in fortification objects, did over $64 \%$ of respondents not indicate any problems with limited access to fortifications. It is interesting that those over 40 years of age did not perceive a need to promote the above-mentioned objects.

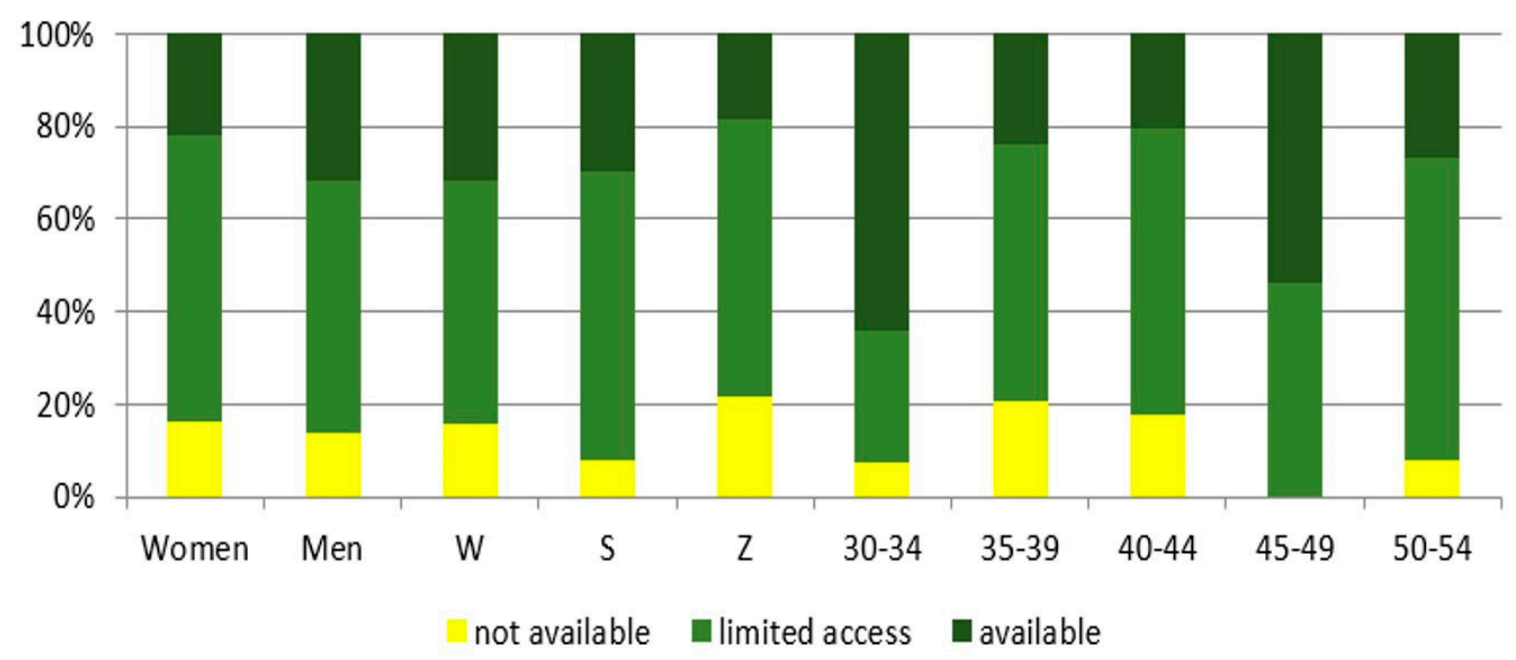

Figure 20. Access to fortress facilities in the respondents' opinion (\%).

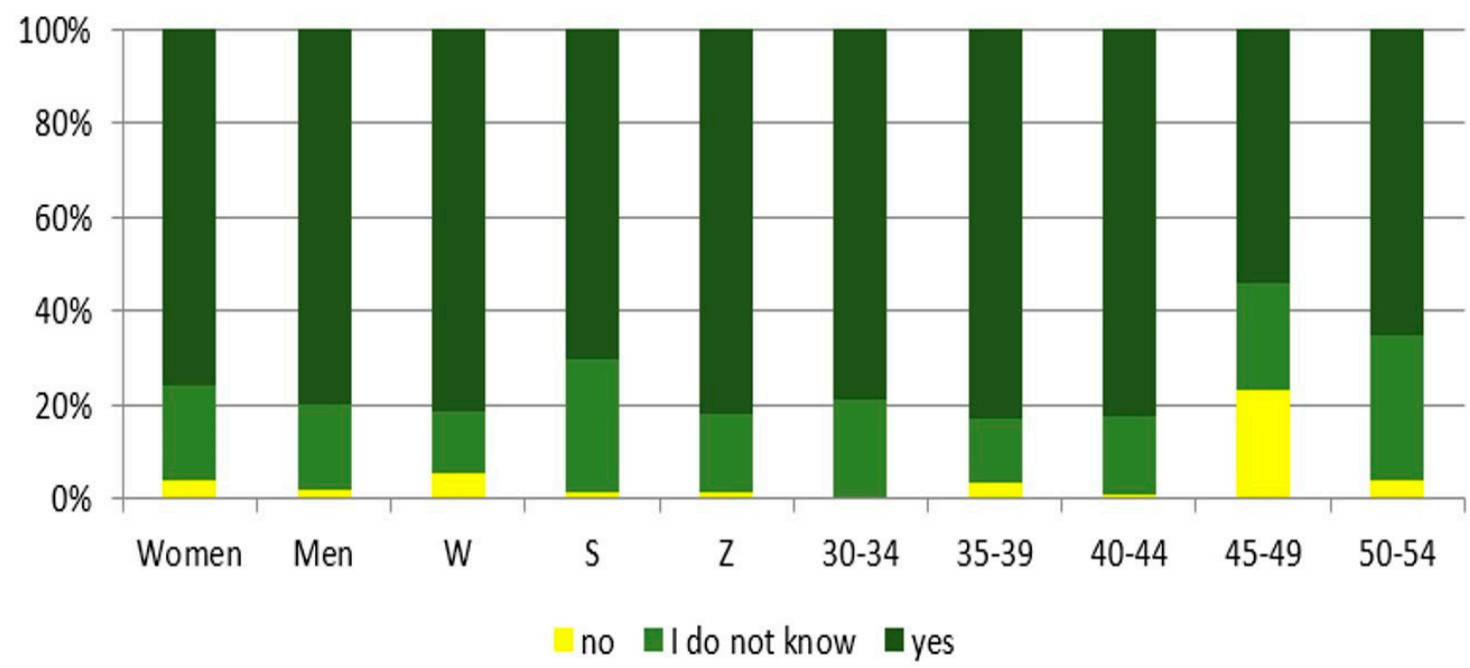

Figure 21. The need to promote and improve the development of fortress facilities by respondents (\%).

The analysis of the data regarding the availability of information on forts, events organized in their area or the possibility of implementing various forms of recreation shows that the most popular sources are Facebook and YouTube. Snapchat, Instagram and Twitter are also popular among women. Men prefer Flickr, Reddit or Tumblr (Figure 22).

The study of the source materials and field vision has shown that most facilities are characterized by good accessibility and only some of them are partially limited. Only two of them are unavailable.

The program implemented in these facilities is very diverse. It is most often associated with the historical background of objects-museums, exhibitions or historical events, such as reconstructions and field games. In some of the facilities various sports activities are organized, including playgrounds, running paths, MTB bike tracks, Nordic walking, rope parks (Bema fort, Włochy Fort), shooting ranges ( $X$ "Augustówka" Fort) and even a diving center (Zbarż Fort). In addition, the area of defensive fortifications allows users to freely arrange any recreational and sporting activities and picnics (e.g., 
Włochy Fort and Rakowiec Fort). Some of the forts are part of housing units and are areas of estate greenery (e.g., VIII "Służew" Fort and Piłsudski Fort). Within the mentioned defensive works, some of the historic buildings, due to their original form, are used as restaurants, clubs, creative work centers, art galleries and architectural and artistic studios (e.g., Traugutt Fort or Mokotów Fort).

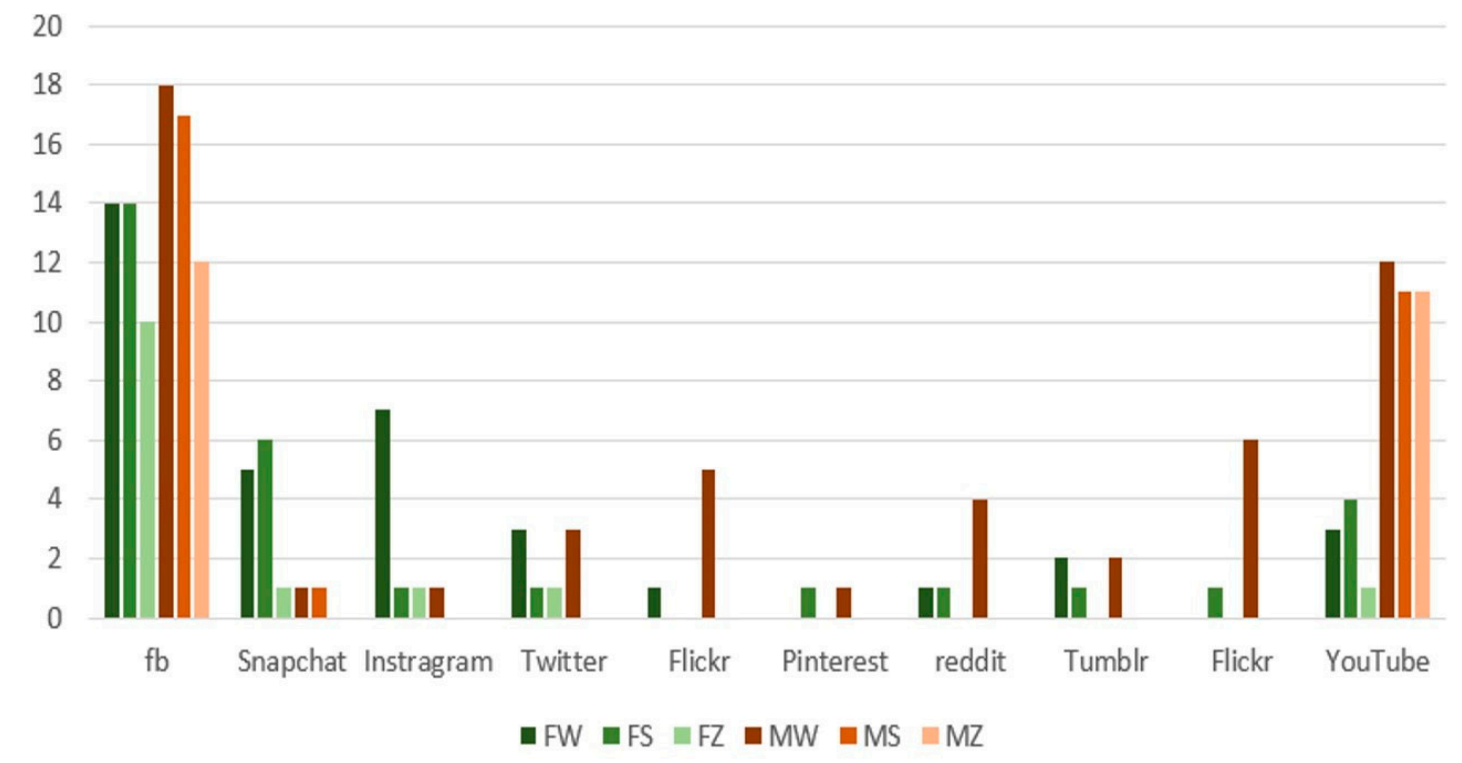

Figure 22. Searching for information on social media: FW/MW—women/men with higher education, FS/MS—women/men with high education, FZ/MZ—women/men with vocational school.

The directions of transformation of the examined fortress buildings forming the Warsaw Fortress were determined on the basis of their development status, manner of use, program and availability $[8,17,31]$.

A degrading direction of changes was observed only in Śliwicki Fort, whose spatial structure was destroyed to build a housing estate. The spatial arrangement has been completely lost and its reconstruction is currently impossible. Only part of the barracks buildings and parts of earth fortifications have survived. However, these remains do not allow the original system to be reproduced.

In the remaining forts, the directions of changes are metamorphic and, at the same time, retaining. Despite the loss of the fortified functions, transformations do not threaten the specific conditional and signaling features of the objects. Within conditional features, it can be seen that the most durable forms of landscape that determined the location of defensive works are still very clearly visible and legible. Regardless of the method of use, these features are not lost. In terms of signal features, i.e., forms of land cover and landscaping that arose as a result of adaptation to military operations, the best features of the terrain have survived. Among them are embankments, moats, access roads, embankments and excavations. Such elements are visible even in the case of the remains of Śliwicki Fort.

Coverage elements including masking stands, observation points and many others were rated as being slightly worse. These elements disappeared during the absorption of objects by the city.

At the same time, it can be seen that this metamorphosis pattern is partly superimposed on this direction of change. The military function ceases to be dominant, or even disappears over tim, to be replaced by cultural functions (museum, educational and exhibition programs) as well as leisure and recreation facilities. In this case, we can talk about two directions of such transformations. The first is associated with targeted and planned changes. The second one is related to the creation of a spontaneous program and great freedom of users.

These changes have no negative impact. One can even risk saying that they add a new value to the objects. Thanks to this, they are even more inscribed in the cultural landscape of the place. 


\section{Discussion}

Complex defense systems, such as the Warsaw Fortress, which are part of city structures, constitute a very important and valuable element of the cultural landscape. It can be stated that through their spatial scale and creating a specific network in space, they can be treated as a place identifier. Due to the fact that vegetation is a very important component of these objects and because of its significant share, these elements are important in the city's natural system. We can also find similar solutions in other Polish cities, such as Toruń, Kraków, Poznań and Przemyśl. Some other European examples can also be found [32], including the Bountarge Fortress in the Netherlands.

Analyzing the topic of fortress landscapes in the context of the structure of cities and their cultural landscapes, it is rather difficult to find analogical solutions to the situation of the Warsaw Fortress or other ring objects. Above all, this is due to the fact that the ring fortresses are not widely used and there are not many such structures. Most of them are located in Poland. For this reason, it can be assumed that the military cultural landscape connected with the matter of the city is a kind of trademark, an element encountered mostly in Poland. While trying to compare the Fortress of Warsaw with similar objects, analogies can only be found with e.g., the Poznan Fortress or the Krakow Fortress. In these cities, a very similar structure and method of absorption of objects by the city can be observed. In each of these cases, a high value of objects along with a high degree of preservation of the historical tissue and expanding program dedicated to both qualified and casual users are to be noticed.

Moreover, all the facilities play a very significant role in shaping the city's natural system on a local scale-as e.g., park nodal buildings facilities, being part of a supra-local system. This is most evident in the case of the Fortress of Warsaw and in the system of aeration wedges, coinciding with the radial arrangement of the forts of both rings.

With the current development status of individual buildings in the Warsaw Fortress, it is stated that the greenery associated with them is predominantly public and accessible without restrictions. Such objects are often left in an unorganized form, being "wild" or publicly available parks as well as semi-public spaces for special purposes, such as museum objects or those that have become part of the estate gardens. Their greenery has a number of natural functions, from climate through hydrological to biological ones. These facilities, therefore, should form the basis of urban strategic planning [33].

Due to their location, individual forts can be considered as nodes of spatial composition of the city and urban natural system. Communication routes partly overlapping with the layout of historic fort roads are very interesting against the background of the city structure.

Similarly, fortress areas in other cities are shaped according to the spatial rules typical for star fortresses: Zamość, Przemyśl or other fortress complexes constitute nodal areas in the city's natural systems such as Peter and Paul Fortress in St. Petersburg, the Komarno Fortress in Slovakia and the Komarno Fortress in Hungary, the New Dutch Waterline [34] or the Boyen Fortress in Poland.

The Fortress of Warsaw as a ring system of fortifications can still be used as an original element of the city's recreational system by creating a coherent, multi-phase program for individual defensive facilities linked by a network of tourist and educational routes at different levels with uniform tourist information. It should be emphasized that the system should never become a fiction due to the freedom of design (more than half of the valuable fortification sites are currently owned by private investors). Similarly, legal protection of preserving large-area monuments in the form of a cultural park should be sought while looking for a coherent development program and a proper way of conducting comprehensive management [35].

Warsaw is a specific city characterized by rapid urban development in the 20th century, which has now far exceeded the boundaries of the outer fortress belt. The preserved "green masks" of the Fortress of Torun, allowing for the reconstruction of the fortress system, are reflected in the system of green areas of Warsaw. These areas are currently considerably fragmented, but remain as a remnant of the pre-war concept of a system of wedges connected by circles, the outline of which still functions in the city's spatial policy. Current ways of using earth objects indicate a lack of interesting ideas and a progressing process of degradation of the preserved fragments. These difficulties result both from the 
unclear ownership situation, the lack of historical documentation or simply the need to change the function so that it could meet the expectations of the constantly developing city while not losing its didactic value-the message regarding the region's traditions, possibilities of military art and historical events. The functions connected with recreation, i.e., the incorporation of the elements of the fortress into the system of urban recreation would certainly make this offer much more varied. It is important that the offered program allows the use of the facility for the longest possible period of time during the year while being intended for the widest possible age group. The creation of a coherent program requires the creation of an institution managing a large cultural landscape. The first experiences of this type prove that, first of all, an institution seeking funds for its maintenance in cooperation with a group of professional advisors and local social organizations achieves the planned effects more quickly than the creation of such an institution by adding competences to city officials.

Analyzing the layout of the forts of the Warsaw Fortress and the transit routes connecting individual elements, it is possible to conclude that today Warsaw can be a city that should develop its natural system according to the most optimal city model—a ring-wedge-shaped model—which is related to the specificity of the city's cultural landscape. The outer ring of the fortifications should be functionally and spatially included in the green belt of Warsaw. Using the experience of the green belt network created in London (London's strategic open space network) [36], it is proposed to create a green belt that consists of forests surrounding the city, including Kampinos National Park, Mazowiecki Park and Chojnowski Landscape Park. Significant afforestation areas, accompanying the borders of Warsaw, are another important distinguishing feature of the city's landscape. Among them were also areas related to the fortress landscape: Forty Modlińskie or Bielański Forest.

The fortifications are also attractive to tourists, mainly in the context of leisure [37]. An interesting solution would be extension of the tourist program to include qualified military tourism with the emphasis on the objects' historical value expressed by numerous monuments of national memory [12]. Numerous sources $[25,27,28,38-43]$ indicate that this is one of the most dynamically developing varieties of tourism in Europe [42]. According to estimates, there are about 20,000 fortification objects in Poland referring to various historical periods [41]. The EU document entitled "Agenda for a sustainable and competitive European tourism" mentions a significant increase in tourism related to cultural and natural heritage in Europe in the coming years [37]. Also, the issue of the use of military facilities for tourism, recreation, and popularization and education is increasingly the subject of social interest within the country [44]. The studied area is characterized by great opportunities for the development of military tourism, especially due to the fact that it is located near a large urban unit and there are close distances between individual forts.

Tourism aimed at visiting fortifications is becoming increasingly popular in Poland and Europe. Many cities are trying to take advantage of the opportunities associated with the development of this type of tourism based on exhibiting individual objects but also directing the interest of tourists to the landscape that such objects co-create. As a result, they can admire the landscape, which is an important element of the fortifications. In many cases, e.g., in Torun, a tourist route connecting the fortress facilities has been created. Unfortunately, this type of route does not exist in Warsaw. Individual objects of the fortress have not been connected by any tourist route so far, which makes it difficult to admire the fortress as a whole or visit several objects in one day. An interesting example of this is the fortifications of Gdańsk. In recent years, the Motława River area has been revitalized, including the extremely valuable 17th-century Old Dutch bastion fortifications. Thanks to these activities, the city gained an attractive recreational area in the immediate vicinity of the old town [45]. In Warsaw, post-fortification areas nowadays play the role of city parks, but their fortress past is not exposed in any way, e.g., with the help of a system of information boards. The Citadel constitutes an exception in this respect.

Fragments of the "fortified landscape" are protected, among other areas, in Krakow. Thanks to the carefully developed local spatial development plans prepared by the Spatial Planning Office of Krakow, the areas of St. Bronisław hills and the Fort Skała are preserved [29]. No such planning studies 
have been created in Warsaw so far. However, the idea of the Warsaw Cultural Military Park Fortress has been introduced.

The main reason for "fortification" tourism is citizens' interest in history [12,23], army, armament or technology. To date, no detailed sociological research has been conducted on the profile of military and cultural tourists. However, the analysis of associations of military enthusiasts and historical reproduction allowed to identify the features connecting these types of tourists. First of all, they are well-educated people who are in the age range of 18-30, the second largest age group is represented by people aged 30-45. In addition, they are generally people in good physical condition, possessing specialized equipment [24].

The obtained results clearly indicate that the promotion of the development of military tourism is supported by the fact that the vast majority of the analyzed objects showed signs of social interest [5]. At this point, it is worth paying attention to the significant role of military tourism in shaping the right form of citizenship [13,46].

Military cultural tourism is a type of tourism that meets the cognitive need [43], associated with the military dimension of a specific place. Mikos von Rohrscheidt [47] states that the decisive factor relating to human participation in this type of travel is the desire to explore or visit defensive objects and places that are inseparably connected with the history of armed conflicts, army or or soldiers. Traveling of this type is mainly intended to gain personal experience [48].

The military variant of qualified cultural tourism is mainly focused on fortifications, battlefields, biographies of famous people (commanders, chiefs, heroes), armaments factories, museums completing military equipment, shelters, defense buildings and military camps. The main functions of this type of tourism [48] include the following functions:

- historical and educational (specialized cognitive tourism);

- martyrological;

- political and ideological (shaping patriotic attitudes);

- cultural and entertainment (thematic entertainment);

- recreation and sports (battle reproduction, exploration of military facilities);

- $\quad$ adventure (experience).

In this light, the concept of the Cultural Park Warsaw Fortress fits deeply both as a very important element of the cultural landscape of Warsaw and in the trend of the ecosystem services segment [35].

Referring to tourist attractions related to military cultural tourism, two types can be distinguished [48]: spatial attractions which refer to a given area, having distinguishing features of the geographical environment; and non-spatial attractions, having the form of events. The establishment of the Warsaw Fortress illustrates both types of these attractions.

The geopolitical location of Poland has contributed to the development of fortification art by the construction of defense facilities in major European states in the nineteenth century [49]. Poland is often referred to as the European open-air museum of fortification art. There are 4817 various types of fortification facilities documented within it [32] (this number does not include spatially compact units). However, despite the large number of fortifications, their potential is not fully utilized. To date (10.07.2019), twenty-four cultural parks have been established in Poland, including only two connected with fortifications: the Cultural Park Fortress in Srebrna Góra and the Cultural Park Fortress Twierdza Kłodzka.

\section{Conclusions}

Due to its history and location, Poland is a place where many fortress buildings from different periods are located. Primarily, most of them are related to the period of partitions of Poland. They are also diverse objects which are frequently connected directly with urban structures.

Resulting from their location, many objects are currently within city limits, and their individual elements are still absorbed by urbanized areas, undergoing metamorphosis. An example of a place 
where such changes are occurring is the Warsaw Fortress with the fortresses of both rings. At the same time, these objects constitute an important element of the cultural landscape due to their size and dominance in the composition of the city.

In the case of the Warsaw Fortress, its specific structure with two rings is still clearly visible, strongly connected in terms of composition and communication with the city structure, as well as with the natural system of Warsaw.

In most buildings, apart from the dominant historical and architectural value, there is also a vegetation cover with mature tree stands and specific terrain forms of earth embankments and moats.

Models of fortress plant forms can be an interesting way to include and highlight the presence of forts in a city's structure.

The analyzed objects were rated very highly in both valorization methods used. In the case of the WNET method, the average rating of the cultural landscape accounted for $70 \%$ of the maximum rating, while for the method of landscape criteria, only 7 out of 22 objects scored below the average rating.

In the public perception, fortress objects are perceived as being very valuable, allowing them to implement various forms of recreation. These facilities are also an important element and basis for building qualified military tourism programs, as evidenced by surveys carried out.

The channel for the dissemination of knowledge about forts and information on events organized in their area is Facebook and YouTube. There is also a growing share of other sources. This is an important way to disseminate knowledge about this unique element of the cultural landscape.

Author Contributions: Conceptualization, E.Z.-J.; Formal analysis, E.Z.-J., T.S. and T.K.; Investigation, E.Z.-J.; Methodology, E.Z.-J.; Supervision, B.Ż.; Visualization, J.B.; Writing-original draft, E.Z.-J. All authors have read and agreed to the published version of the manuscript.

Funding: This research received no external funding.

Conflicts of Interest: The authors declare no conflict of interest.

\section{References}

1. Bogdanowski, J. Architektura Obronna w Krajobrazie Polski. Od Biskupina po Westerplatte; PWN: Warszawa-Kraków, Poland, 1996; p. 610.

2. Bogdanowski, J. Krajobraz Warowny XIX/XX Wieku, Dzieje i Rewaloryzacja; PWN: Kraków, Poland, 1993; p. 77.

3. Norgaard, E. Ecosystem services: From eye-opening metaphor to complexity blinder. Ecol. Econ. 2009, 69, 1219-1227. [CrossRef]

4. Verschuure-Stuip, G. Hold the Line: The transformation of the New Dutch Waterline and the Future Possibilities of Heritage, Adaptive Strategies for Water Heritage Past, Present and Future. Available online: https://link.springer.com/chapter/10.1007/978-3-030-00268-8_13 (accessed on 19 January 2020).

5. Charter of European Planning [Europejska Karta Planowania] ECTP-CUE. 2013, Uniwersytet Warszawski, Warszawa. Available online: https://www.yumpu.com/xx/document/read/23086776/europejska-kartaplanowania-barcelona-2013-wizja- (accessed on 10 August 2019).

6. Pharo, E.; Daily, G.C. Nature's Services: Societal Dependence on Natural Ecosystems. Bryology 1998, 101, 475. [CrossRef]

7. Kowalski, M.; Fuszara, M.; Fuszara, E. Sprawozdanie z badań nietoperzy na Lotnisku w Modlinie. 2018. Available online: https://www.modlinairport.pl/sites/default/files/sprawozdania_z_badan_nietoperzy_na_ lotnisku_warszawamodlin_i_terenach_przyleglych_w_roku_2018.pdf (accessed on 4 November 2018).

8. Potthof, H. Trendy w Europejskiej Turystyce Wiejskiej. Agroturystyka a Rozwój Wsi; Centrum Doradztwa i Edukacji w Rolnictwie: Kraków, Poland, 1993; pp. 21-22.

9. Jędrysiak, T.; von Rohrscheidt, A.M.; Ekonomiczne, P.W. Rozwój militarnej turystyki kulturowej w Polsce-wnioski i postulaty. In Militarna Turystyka Kulturowa; PWE: Warszawa, Poland, 2011; pp. 116-134.

10. Środulska-Wielgus, J. Przyrodnicze elementy w tworzeniu i maskowaniu fortyfikacji. Forteca 1997, 9, 3-14.

11. Zaraś-Januszkiewicz, E.; Graziewicz, A. Greenery forming of the Boyen Fortress. Annals of Warsaw university of life sciences-SGGW. Hort. Land. Arch. 2008, 29, 105-120. 
12. Wieczorek, J. Wstęp, Pomniki Pamięci Narodowej; Rada Ochrony Pomników Walki i Męczeństwa: Warszawa, Poland, 1970; pp. 5-7.

13. Stephens, J. Remembering the Wars: documenting memorials and war commemoration in Western Australia. J. Arch. 2010, 15, 637-650. [CrossRef]

14. Instrukcja techniczna. Przegląd mierniczy 1913 No 2 1925. Available online: http://bcpw.bg.pw.edu.pl/ Content/6536/pm25_nr02.pdf. (accessed on 22 September 2018).

15. Capelo, S.; Fhemudo, T.; de Mascarenhas, J. Why are cultural landscapes of various values? Thinking about heritage landscape evaluation and monitoring tools. J. Land. Ecol. 2011, 4-10. [CrossRef]

16. Piatek, U.M. Kryteria i metody oceny krajobrazu kulturowego w procesie planowania przestrzennego na tle obowiąujacych procedur prawnych, Environmental assessment in physical planning. In The Problems of Landscape Ecology; Kistowski, M., Korwel-Lejkowska, B., Eds.; University of Gdańsk, Institute of Geography: Gdańsk, Warszawa, 2007; Volume XIX, pp. 101-110. Available online: http://paek.ukw.edu.pl/pek/index.php/ PEK/article/view/3731 (accessed on 24 November 2017).

17. Military Heritage Management Guidelines. 2011. Available online: https://www.ttu.ee/public/k/Kuressaarekolledz/Kolledz/Summer_school/Military_Heritage_Management_Guidelines_2011.pdf. (accessed on 11 March 2018).

18. Pałubska, K. The Greenery and Natural Terrain Obstacles from the Warsaw Fortress that Shaped the City's Ecological System. Arch. Kraj. 2014, 2, 50-61.

19. Litwin, U.; Bacior, S.; Piech, I. Metodyka waloryzacji i oceny krajobrazu, 2009, Geodezja, Kartografia i Fotografia lotnicza, No 71 14-25 Uniwersytet Rolniczy w Krakowie McKercher B. du Cros H. Cultural Tourism: The partnership between tourism and cultural heritage management. 2002, Routledge. Available online: http://ena.lp.edu.ua/handle/ntb/6991 (accessed on 11 January 2019).

20. Metody Oceny Krajobrazu Kulturowego. Available online: http://urbnews.pl/metody-oceny-krajobrazukulturowego/ (accessed on 2 October 2019).

21. Królikowski, L. Twierdza Warszawa; PWN: Warszawa, Poland, 1994; p. 155.

22. Dirka, I.; Dika, R.; Ani, B.; Krklec, K.; Andlar, G.; Hrdalo, I.; Perekovi, P. Cultural landscape evaluation and possibilities for future development-a case study of the island of Krk (Croatia). Acta Geo. Slov. 2011, 51, 129-150.

23. Golińska, M.; Herman, A.; Przybyłowska, D. Twierdza Warszawa 2015. Available online: https://www. slideshare.net/dariaprzybylowska/twierdza-warszawa-koniec (accessed on 23 October 2018).

24. Pałubska, K. Zarzadzanie Krajobrazem Kulturowym Prace Komisji Krajobrazu Kulturowego Nr 10; Komisja Krajobrazu Kulturowego PTG: Sosnowiec, Poland, 2008; pp. 471-479.

25. Różańska, A.; Krogulec, T. Przyroda i Miasto. Tom X. Część II; Mury i wały miejskie jako czynnik kształtujący krajobraz Warszawy; Wydawnictwo SGGW: Warszawa, Poland, 2007; pp. 158-166.

26. Różańska, A.; Rybak, K. Twierdza Warszawa, Twierdza Poznań-rola fortyfikacji w kształtowaniu zieleni miejskiej. In Fortyfikacje w Przestrzeni Miasta; Wilkaniec, A., Wichrowski, M., Eds.; Wydawnictwo Uniwersytetu Przyrodniczego w Poznaniu: Poznań, Poland, 2006; pp. 164-170.

27. Greg, R. Cultural Tourism: Global and Local Perspectives; Routledge: New York, NY, USA, 2007.

28. Janeczko, E.; Heise, M. Możliwości rozwoju turystyki militarnej w lasach na przykładzie nadleśnictwa Wejherowo. Stud. Mat. 2013, 37, 137-143.

29. Jęrysiak, T.; von Rohrscheidt, A.M. Militarna Turystyka Kulturowa; Polskie Wydawnictwo Ekonomiczne: Warszawa, Poland, 2011; p. 280.

30. Kaczorowska, M. Miejscowe plany zagospodarowania przestrzennego Wzgórze św. Bronisławy oraz Rejon Fortu Skała w Krakowie. In Fortyfikacje w Przestrzeni Miasta; Wydawnictwo Akademii Rolniczej im. Augusta Cieszkowskiego w Poznaniu: Poznań, Poland, 2007; pp. 77-99.

31. Molski, P. Ochrona i Zagospodarowanie Wybranych Zespołów Fortyfikacji Nowszej w Polsce, Architektura, Tom 3; Oficyna Wydawnicza Politechniki Warszawskiej: Warszawa, Poland, 2007; pp. 3-132.

32. Pratt, C.J.H. Routeing in military tourism: gamification as an implementation proposal Polictechnica de Tomar Escola Superior de Gestão de Tomar 2015. Available online: https: //comum.rcaap.pt/bitstream/10400.26/18605/1/Pratt\%2C\%20C.\%20ROUTEING\%20IN\%20MILITARY\% 20TOURISM\%20Gamification.pdfInsituto,dostep10lutego2019r (accessed on 8 April 2018).

33. Cheal, F.; Griffin, T. Pilgrims and patriots: Australian tourist experiences at Gallipoli. Int. J. Culture Tour. Hosp. Res. 2013, 7, 227-241. [CrossRef] 
34. Hold the Line: The transformationof the New Dutch Waterlineand the Future Possibilities of Heritage. Available online: https://link.springer.com/content/pdf/10.1007\%2F978-3-030-00268-8_13.pdf (accessed on 19 January 2020).

35. Parki Kulturowe. Available online: https://www.nid.pl/pl/Dla_wlascicieli_i_zarzadcow/dla-samorzadow/ parki-kulturowe/ (accessed on 2 October 2019).

36. Pszenny, D.; Janeczko, E. Zielony Pierścień Warszawy jako obszar rozwoju turystyki militarnej. Studia Materiaty CEPL Rogowie 2015, 45, 180-186.

37. Riechers, M.; Strack, M.; Barkmann, J.; Tscharntke, T. Cultural Ecosystem Services Provided by Urban Green Change along an Urban-Periurban Gradient. Sustainability 2019, 11, 645. [CrossRef]

38. Ivanovic, M. Cultural Tourism; Juta and Company Ltd.: Claremont, Australia, 2009; p. 337.

39. Nagy, K. Heritage Tourism, Thematic Routes and Possibilities for Innovation. Theo. Meth. Prac. 2012, 8, 46-53.

40. Richards, G.W. The Impact of Culture on Tourism. OECD. Available online: https://www.academia.edu/ 2411575/The_Impact_of_Culture_on_Tourism (accessed on 11 September 2018).

41. Poczta, J. Turystyka Militarna Jako Przejaw Nowej Formy Aktywności Turystycznej w Polsce. Turystyka i Rekreacja Jako Formy Aktywności Społecznej; Wielkopolska Wyższa Szkoła Turystyki i Zarządzania: Poznań, Poland, 2008; pp. 139-146.

42. Richards, G. Cultural Tourism in Europe. Available online: www.tram-research.com/atlas. (accessed on 12 September 2019).

43. Venter, D. Examining military heritage tourism as a niche tourism market in the South African context African Journal of Hospitality. Tour. Leisur. 2017, 6, 1-19.

44. Borowiecki, K.J.; Castiglione, C. Cultural participation and tourism flows: An empirical investigation of Italian provinces. Tour. Econ. 2014, 20, 241-262. [CrossRef]

45. Klupsz, L. Miejsce Fortyfikacji we Współczesnych Aglomeracjach. In Fortyfikacje w Przestrzeni Miasta; Wydawnictwo Akademii Rolniczej im. Augusta Cieszkowskiego w Poznaniu: Poznań, Poland, 2007; pp. 57-71.

46. VanderWolk, W. Victor Hugo in Exile: From Historical Representations to Utopian Vistas; Bucknell University Press: Cranbury, NJ, USA, 2006; p. 457.

47. Von Rohrscheidt, A.D. Turystyka Kulturowa. Fenomen, Potencjat, Perspektywy; Wyd. GWSHM Milenium: Gniezno, Poland, 2008; p. 477.

48. Niedźwiecka-Filipiak, I.; Rubaszek, J.; Potyrała, J.; Filipiak, P. The Method of Planning Green Infrastructure System with the Use of Landscape-Functional Units (Method LaFU) and its Implementation in the Wrocław Functional Area (Poland). Sustainability 2019, 11, 394. [CrossRef]

49. Stach, E. Analiza stanu zagospodarowania obiektów na Szlaku Twierdzy Kraków-możliwości ich adaptacji do współczesnych funkcji turystycznych i rekreacyjnych. In Zamki i Twierdze w Rozwoju Wspótczesnej Turystyki; Boruszczak, M., Ed.; Wyższa Szkoła Turystyki i Hotelarstwa w Gdańsku: Gdańsk, Poland, 2013; pp. 39-54. 